\title{
Engineering Geologic Conditions at the Sinkhole Entrance to Logan Cave, Benton County, Arkansas
}

By William H. Schulz and Jonathan P. McKenna

Open-File Reports are used for the dissemination of information that must be released immediately to fill a public need or for information that is not sufficiently refined to warrant formal publication. As such, Open-File Reports should not be viewed as final reports of major scientific investigations. Because of their preliminary nature and possibility of being superseded, Open-File Reports do not introduce new or revised geologic, stratigraphic, hydrologic, or taxonomic nomenclature. In particular, Article 4(a) of the North American Stratigraphic Code excludes open-file releases for the naming or revising of formal geologic units.

Any use of trade, firm, or product names is for descriptive purposes only and does not imply endorsement by the U.S. Government.

\section{U.S. Geological Survey Open-File Report 2004-1357}

\author{
U.S. Department of the Interior \\ U.S. Geological Survey
}




\section{ABSTRACT}

Logan Cave, located in Benton County, Arkansas, is inhabited by several endangered and threatened species. The cave and surrounding area was designated a National Wildlife Refuge under the control of the U.S. Fish and Wildlife Service (USFWS) in 1989. Cave researchers access the cave through a steep-sided sinkhole entrance, which also is one of the two access points used by endangered bats. There is evidence of instability of one of the entrance slopes that has raised concerns that the entrance could close if slope failure was to occur. At the request of USFWS, we performed an engineering geologic investigation of the sinkhole to evaluate stability of this slope, which is comprised of soil, and other mechanisms of sediment transport into the cave entrance. The investigation included engineering geologic mapping, sampling and laboratory testing of subsurface geologic materials, and slope-stability analysis. We found that the sinkhole slope that extends into the entrance of the cave is comprised of sandy and gravelly soil to the depths explored (6.4 meters). This soil likely was deposited as alluvium within a previous, larger sinkhole. Based on properties of the alluvium, geometry of the slope, and results of finite-element slope-stability analyses, we conclude that the slope is marginally stable. Future failures of the slope probably would be relatively thin and small, thus several would be required to completely close the cave entrance. However, sediment is accumulating within the cave entrance due to foot traffic of those accessing the cave, surface-water erosion and transport, and shallow slope failures from the other sinkhole slopes. We conclude that the entrance will be closed by sediment in the future, similar to another entrance that we identified that completely closed in the past. Several measures could be taken to reduce the potential for closure of the cave entrance, including periodic sediment removal, installation of materials that reduce erosion by foot traffic and surface water, construction of a sediment-retention wall, and excavation of the soil slope. Any measures taken must be carefully planned and executed so that they have no impact on organisms within the cave.

\section{INTRODUCTION}

Logan Cave National Wildlife Refuge (LCNWR) covers $0.5 \mathrm{~km}^{2}$ (123 acres) in Benton County, Arkansas, and includes a limestone solution cave with approximately $2.4 \mathrm{~km}(1.5 \mathrm{mi})$ of mapped passageways (http://southeast.fws.gov/LoganCave/). The refuge was established in 1989 to protect cave inhabitants, including the endangered gray bat (Myotis grisescens) and cave crayfish (Cambarus aculabrum), and the threatened Ozark cavefish (Amblyopsis rosae). Logan Cave is one of only four known habitats for the cave crayfish, and its Ozark cavefish population is the second largest known. The cave also has historically provided habitat for the Indiana bat (Myotis sodalis). The U.S. Fish and Wildlife Service (USFWS) scientists and others are concerned that instability of a slope area above the main cave entrance could result in destruction of the habitat for the threatened and endangered species within the cave.
The main entrance to Logan Cave through which bats, USFWS scientists, and other researchers gain access is a small opening at the base of a steep-sided sinkhole. Observations made within the cave entrance by these scientists indicate that soil (defined as unconsolidated mineral and organic material) mantling bedrock within the sinkhole is potentially unstable and could conceivably close the entrance. Such a closure would most likely have adverse impacts on the gray bat, cavefish, and crayfish populations. Furthermore, scientists could be trapped within the cave, should a slope failure occur while they are inside. To address these concerns, the USFWS contacted the U.S. Geological Survey (USGS) and requested that we perform an investigation of the stability of the soil mantling the sinkhole above the entrance to Logan Cave. This investigation was performed during the summer of 2004 and is described herein. David Kampwerth and Carla Mitchell of the USFWS Arkansas Field Office and Holla Bend Refuge, respectively, provided access to the refuge, a site orientation, logistic support, and valuable information regarding the cave and slope-stability concerns. Our investigation included obtaining and examining aerial photographs of the area and the available literature regarding regional geologic conditions, discussions with USFWS personnel, engineering geologic mapping at the refuge, sampling and logging of potentially unstable soils, laboratory testing of these soils, slope-stability analyses, and analysis of our findings.

\section{Setting}

The LCNWR is located near the northwest corner of Arkansas (fig. 1) in an area of moderate relief dissected by mature drainages. The refuge is covered by oak-hickory forest and undergrowth (U.S. Department of Agriculture, 1977). According to the USGS Gallatin 7.5-minute topographic quadrangle (1982), elevations decrease within the refuge from about $380 \mathrm{~m}$ $(1200 \mathrm{ft})$ in its northwestern corner to $310 \mathrm{~m}$ (1000 ft) along its southern boundary. A series of southeast-trending ridges and valleys extend through the refuge with local relief of up to about $30 \mathrm{~m}$ (98 ft), and slopes inclined as steeply as about $30^{\circ}$. The sinkhole entrance to Logan Cave is located along a flank of one of these ridges. Springs within Logan Cave form a stream with a measured flow of about $0.22 \mathrm{~m}^{3} / \mathrm{s}\left(5.0 \times 10^{6} \mathrm{gal} / \mathrm{d}\right)(\mathrm{http}: / /$ southeast.fws.gov/LoganCave/). This stream forms Logan Spring, which drains to Osage Creek just south of the refuge. Osage Creek is a major tributary of the Illinois River, which is the main drainage in southwestern Benton County, and their confluence is about $2 \mathrm{~km}$ (1.2 mi) south of the refuge.

\section{Geologic Setting}

The LCNWR is located within the Springfield Plateau geologic province on the southwest flank of the Ozark Dome, which is a broad uplift centered in southeast Missouri (Manger and others, 1988b). The Springfield Plateau is comprised of bedrock units formed from sediments deposited by Paleozoic seas (Manger and others, 1988a). These bedrock units dip gently to the south (Guccione and Rieper, 1988), and many are cut by normal faults with downward motion on their south sides (Manger and others, 


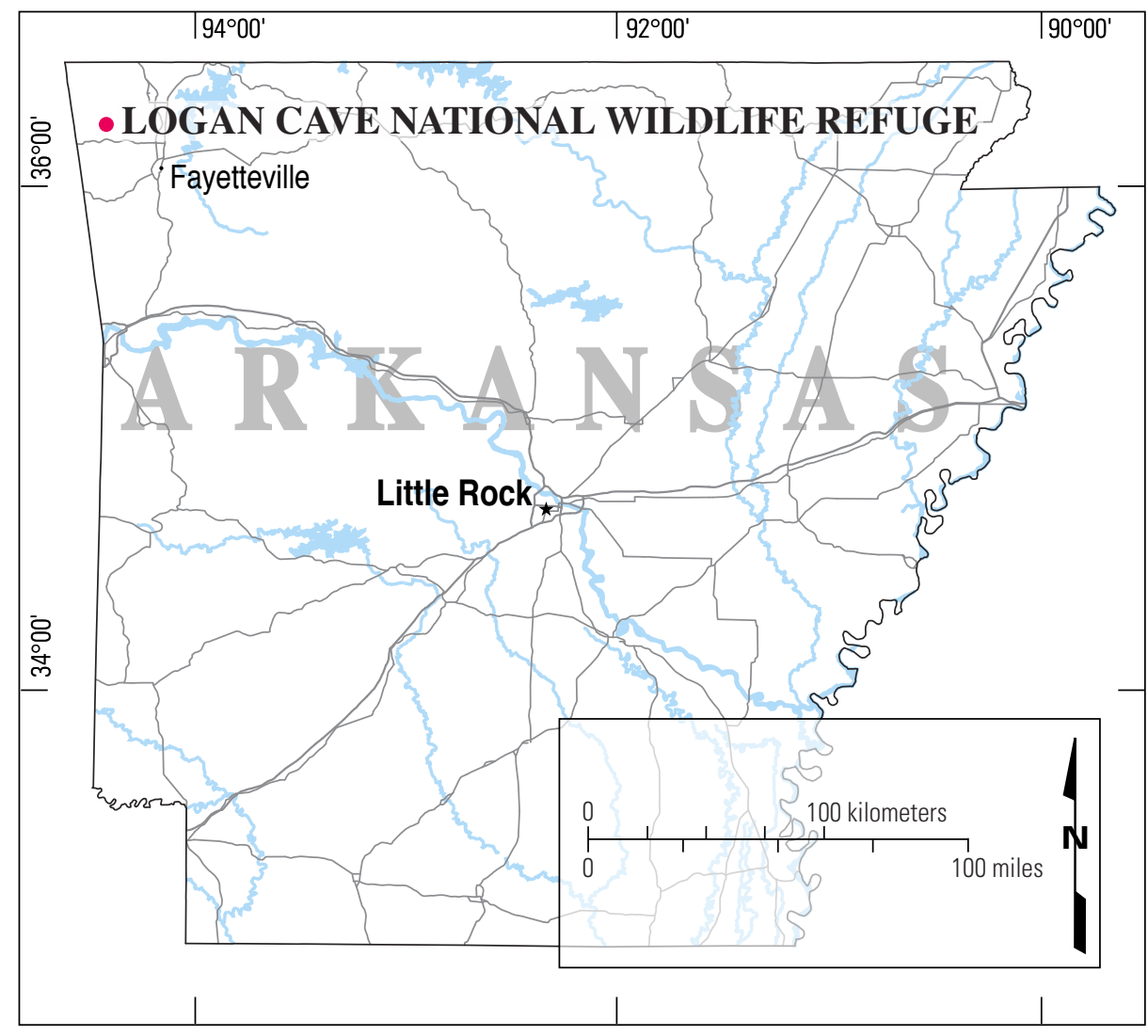

Figure 1. Map of Arkansas showing location of Logan Cave National Wildlife Refuge

1988b). The upper part of the Springfield Plateau is composed of cherty limestone of the Lower Mississippian Boone Formation, which is underlain by chert-free limestone of the St. Joe Formation (Manger and others, 1988b).

The Boone and St. Joe Formations form the dominant ground water aquifer in northwestern Arkansas (Martin, 1994). Chert content within the Boone Formation ranges from a few to 70 percent (Martin and Brahana, 1995), and laterally extensive chert layers have been observed to perch ground water at different zones within the formation (Goodman and Mack, 1985). Overall, ground water within the Boone-St. Joe aquifer is perched upon the underlying Chattanooga Shale (Martin, 1994; Stanton, 1994). Both the Boone and St. Joe Formations are dissected by numerous caves and solution channels. Ground water flow within the Boone-St. Joe aquifer occurs preferentially through solution channels (including caves), fault zones, and fractures (Smith, 1994; Bostian and Brahana, 1996). Single well pump tests within the Boone-St. Joe aquifer have yielded specific capacity values that range from $2.5 \times 10^{-4}$ to $0.37 \mathrm{~m} / \mathrm{d} / \mathrm{m}(0.02$ to $30 \mathrm{gal} / \mathrm{min} /$ ft) (Rezaie and others, 1979; Ogden, 1980). This significant variability is caused by the lack or presence of fractures, faults, and solution channels. The widespread occurrence of solution channels also affects surface water, resulting in disappearing streams and springs throughout the area (for example, Rezaie and others, 1979; Ogden, 1980; Manger and others, 1988b; Martin and Brahana, 1995). More than 90 percent of springs in northwest Arkansas with discharge in excess of $0.15 \mathrm{~m}^{3} / \mathrm{s}\left(3.4 \times 10^{6} \mathrm{gal} /\right.$ d) are within $500 \mathrm{~m}(1600 \mathrm{ft})$ of faults, and many fault zones and fault-related fractures have associated parallel caves and solution channels that formed by preferential ground water flow (Bartholmey and others, 1995).

The LCNWR is underlain by generally flat-lying bedrock of the Boone Formation (Haley, 1993), or possibly by the St. Joe Formation (Manger and others, 1988a). Haley (1993) did not map the St. Joe Formation, although it is described by others (for example, Rezaie and others, 1979; Ogden, 1980; Goodman and Mack, 1985; Manger and others, 1988a, 1988b; Martin and Brahana, 1995). Chattanooga Shale is mapped just beyond the southern boundary of the refuge (Haley, 1993) so it probably underlies the Boone or St. Joe Formation at shallow depth below the refuge. The shale is exposed to the south because elevations in the area decrease to the south. A normal fault is mapped along the east boundary of the refuge (Haley, 1993). The regional water table, which occurs in the St. Joe-Boone aquifer, has been mapped at a depth of $23 \mathrm{~m}(75 \mathrm{ft})$ in the vicinity of the sinkhole entrance to Logan Cave (Ogden, 1979). It seems that Logan Cave may have formed because ground water perched on chert beds or low-permeability limestone beds flowed preferentially through fractures formed by tectonic activity on the nearby fault, resulting in dissolution of surrounding limestone.

According to the Soil Survey of Benton County, Arkansas (U.S. Department of Agriculture, 1977), Clarksville series soils cover the majority of the hillslopes near Logan Cave, whereas Nixa series soils cover the ridgetops. Clarksville soils form 
from very cherty limestone and generally consist of a cherty silt loam with high permeability and moderate strength. These soils typically are classified in accordance with the Unified Soil Classification System (USCS; Naval Facilities Engineering Command, 1986) as silty, clayey, or poorly graded gravel (GM, GC, and GP, respectively). The fine-grained fraction of Clarksville soils is non-plastic to slightly plastic (USCS group symbols of CL and ML) and has low potential for swelling and shrinking with variations in moisture content. Nixa series soils are very similar to Clarksville soils, except that the Nixa soils have very low permeability. Both soil series generally are brown to yellowish brown, although the Nixa soils grade to reddish brown near bedrock. Both soil series grade into weathered bedrock and fill fractures within the upper parts of the bedrock.

\section{INVESTIGATION TECHNIQUES}

Our investigation included office, field, and laboratory work. We obtained and evaluated pertinent documents prior to our field investigation to provide us with background information on the topographic and geologic conditions of the refuge. We then performed a field investigation to characterize the conditions of the sinkhole entrance to Logan Cave and supplemented that characterization with laboratory tests. Finally, we evaluated the results of our field and laboratory work and performed analyses of possible future conditions of the sinkhole entrance.

\section{Field Investigation}

Our field investigation was performed July 26-29, 2004, and involved engineering geologic mapping and subsurface sampling. We created a base map of the area around the sinkhole entrance by surveying selected points using a total-station theodolite. We established a local coordinate system that we registered to compass directions by using a pocket transit. Surveyed points were flagged in the field for identification during engineering geologic mapping. The base map was completed by plotting all surveyed points at 1:120 scale using graphing software. The base map was supplemented by measurements made with a pocket transit, tape measure, and a laser rangefinder/hypsometer. Engineering geologic conditions then were mapped onto the base map while at the refuge. The final map is provided on Plate 1.

Subsurface materials were sampled at eight locations within and around the sinkhole entrance to Logan Cave. At seven locations (pl. 1), direct-push subsurface sampling equipment was used to obtain samples at depths up to $6.4 \mathrm{~m}(21 \mathrm{ft})$. This equipment consists of a $0.6-\mathrm{m}$ (2-ft) -long, $5.1-\mathrm{cm}$ (2-in) -diameter, cylindrical steel sampler into which clear, disposable, cylindrical plastic liners are inserted prior to sampling. The sampler was typically advanced in $0.6-\mathrm{m}$ (2-ft) increments by using a 22-kg (48-lb), electric breaker hammer, then withdrawn by using a hand- or foot-operated jack. Upon retrieval from the direct-push hole, the plastic liner and sample within the liner were removed from the steel sampler, and the soil then was removed from the plastic liner. The composition and characteristics of each sample were evaluated and recorded on logs (Appendix A), after which the samples were placed in plastic bags, sealed, and labeled. Subsequent samples were obtained from progressively greater depths by installing a new liner and advancing the sampler down the same hole. Steel rods were threaded onto the sampler to collect soil from depths greater

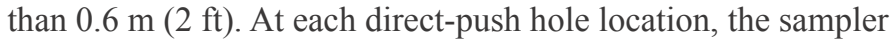
was advanced to sufficient depth to permit characterization of near-surface geologic materials, or until refusal to advance was encountered. Refusal to advance the direct-push equipment may be caused by bedrock or by cobble-sized and larger rocks. Upon completion of each direct-push hole and prior to leaving the refuge, we used an electronic water-level sensor to determine the presence of water in each of the holes; however, all holes were dry.

At one location within the entrance to Logan Cave (pl. 1; labeled TS on the Southwest-Slope Geologic Map), two thinwalled, 7.2-cm (2.8-in) -diameter, cylindrical steel samplers were advanced by hand using a 1-kg (2.2 lb) hammer and drive block. These tube samples were collected for laboratory strength tests, which require a larger sample diameter and less disturbance than is possible by using the direct-push equipment. The samplers were driven from the ground surface to depths of approximately $30 \mathrm{~cm}$ (12 in) and withdrawn. The sampler ends were capped and were taped to prevent loss of soil and moisture.

\section{Laboratory Investigation}

All samples collected during the field investigation were returned to our laboratory in Golden, Colo. We performed moisture-content tests in accordance with ASTM D 2216 (American Society for Testing and Materials, 2002) on all samples obtained from the direct-push holes. We determined the particle-size distributions (ASTM D 422; American Society for Testing and Materials, 2002), plastic and liquid limits, and plasticity indices (ASTM D 4318; American Society for Testing and Materials, 2002) of four samples in accordance with American Society for Testing and Materials standards. The two tube samples were packaged and were shipped to Cooper Testing Laboratories (CTL) of Mountain View, Calif., for tests to determine strength parameters, plastic limits, liquid limits, and unit weight. CTL performed a consolidated, undrained, triaxialcompressive-strength test with pore-pressure measurements on the samples in general accordance with ASTM D 4767 (American Society for Testing and Materials, 2002), and the authors' loading and drainage specifications. The loading and drainage specifications were selected to represent the conditions to which the slope above the sinkhole entrance may be subjected. The test was performed in multiple stages (multistage test) on a remolded (reconstructed) sample. All laboratory test results are provided in Appendix B.

\section{FINDINGS}

\section{Site Conditions}

Topographic and geologic conditions present at the sinkhole entrance to Logan Cave as determined during this study are 
depicted on the geologic maps and cross section (pl. 1). Two maps are included on the plate; a standard geologic map that shows surficial geology and topography and a geologic map with a "window" that shows a view of the part of the southwest slope of the sinkhole that extends into the cave. The map with the window was created to more clearly depict the conditions that we addressed during our study; stability conditions of the soil (mapped on pl. 1 as Qal) slope above the sinkhole entrance. As shown on the Southwest-Slope Geologic Map, the soil (Qal) slope extends from the sinkhole rim to the stream within Logan Cave. Note that topographic contour lines along the cave roof and northeast side have been omitted from both geologic maps to improve clarity.

The sinkhole entrance to Logan Cave is located along an intermittent, south-trending drainage that is deeply incised (about 8-m (26-ft) deep with $22^{\circ}$ side slopes just north of the cave entrance) and displayed evidence of recent surface-water flow at the time of our field investigation. The catchment area of this drainage is about $12,100 \mathrm{~m}^{2}\left(130,000 \mathrm{ft}^{2}\right)$. As indicated on the geologic maps (pl. 1), most of the flow within this drainage probably is captured by the sinkhole. The drainage continues south of the sinkhole where it broadens before merging with another intermittent drainage a few tens of meters away. Thin sandy, subangular limestone and chert gravel (Qal on pl. 1) was observed along the drainage axis north of the sinkhole. The drainage enters the sinkhole at its northernmost point and exposes limestone bedrock along a series of small waterfalls, the last of which is about 2-m (7-ft) high. From the base of the falls, the drainage changes course as it approaches and enters Logan Cave, eventually draining to the northeast and into the stream within Logan Cave (pl. 1).

The sinkhole within which the entrance to Logan Cave is located is roughly rectangular in map view with width and length of about 10 and $24 \mathrm{~m}$ (33 and $79 \mathrm{ft}$ ), respectively, and a maximum depth of about $15 \mathrm{~m}(49 \mathrm{ft})(\mathrm{pl} .1)$. The long axis of the sinkhole is oriented nearly northwest to southeast and the short axis about northeast to southwest. The perimeter of the sinkhole is marked by an abrupt slope break, with slope angles increasing from $0^{\circ}$ to $23^{\circ}$ outside of the sinkhole to between $45^{\circ}$ and $55^{\circ}$ within the sinkhole. Much of the rim of the sinkhole displays evidence of episodic, small-scale landsliding and erosion by surface water, such as fresh exposures of geologic materials, disturbed and overhanging vegetation, and rills. We also observed evidence of ground water seepage from shallow soil (Qr on pl. 1) mantling bedrock along parts of the sinkhole rim. Limestone bedrock is nearly continuously exposed along the northeast slope of the sinkhole and is sporadically exposed along the southeast and northwest slopes. Only the southwest slope of the sinkhole is underlain by soil to significant depth, thus likely has the greatest potential for landsliding. Therefore, the southwest slope was the primary subject of our investigation.

\section{Southwest Sinkhole Slope}

The southwest slope of the sinkhole has a generally consistent inclination of about $47^{\circ}$, although it flattens to about $28^{\circ}$ in its lower part just upslope of the cave. The slope is sporadically vegetated with immature bushes and trees. A nearly $3-\mathrm{m}$ (10-ft) -deep, northeast-trending gully has been eroded through the sinkhole rim near the southern end of the southwest slope (pl. 1; geologic maps). This gully has side slopes inclined as steeply as $71^{\circ}$ and provides the main access to the cave entrance.

The surface of the southwest slope, the gully through the sinkhole rim, and the west part of the southeast slope are covered by sandy, gravelly soil (Qal on pl. 1). Inside the cave, intermittent drainages have eroded as much as $30 \mathrm{~cm}$ (12 in) of this gravel down to the limestone bedrock. Other bedrock exposures were observed protruding through the gravel, indicating that only thin soil mantles bedrock within the cave. We advanced two directpush holes immediately outside of the cave entrance (GS-2 and GS-3, Appendix A and pl. 1). At GS-2, we encountered sand and gravel soil to a depth of $1.4 \mathrm{~m}(4.6 \mathrm{ft})$, where refusal occurred. We advanced GS-3 about $2 \mathrm{~m}$ (7 ft) north of GS-2 in an attempt to determine if bedrock caused refusal. At GS-3, we encountered refusal at $3.4 \mathrm{~m}(11 \mathrm{ft})$ and determined that gravel and sand extend to at least this depth (Appendix A and pl. 1; Geologic Cross Section). As shown on the Geologic Cross Section, GS-3 indicates that soil extends to greater depth than the cave floor just outside the cave, whereas bedrock can be observed at the ground surface a meter away inside the cave. The soil obtained from

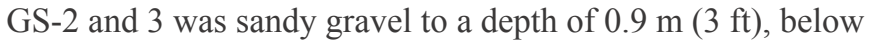
which it was gravelly sand (Appendix A). GS-1 was advanced southwest of the southwest rim of the sinkhole (pl. 1; geologic maps and cross section) and revealed sandy gravel to a depth of $6.4 \mathrm{~m}$ (21 ft) (Appendix A). Refusal was encountered at $6.2 \mathrm{~m}$ (20 ft) following removal of the 5.8-6.4-m (19-21-ft) sample, indicating that collapse of the hole occurred and that material that collapsed into the hole caused refusal, rather than bedrock. Finally, GS-7 was advanced west of the sinkhole (pl. 1; geologic maps) and revealed that sandy gravel extends to a depth of at least $3.6 \mathrm{~m}(12 \mathrm{ft})$ in this location (Appendix A).

Several large blocks of limestone were observed at the base of the falls of the north drainage and within the cave, but these isolated blocks are not shown on the geologic maps. Similarly, isolated exposures of bedrock through the thin soil on the slope within the cave are not shown. In addition, much of the soil mapped on the lower parts of the southwest slope (Qal on pl. 1) has experienced additional transport by shallow landsliding, foot traffic, and surface water since initial deposition. Therefore, it would be more proper to map this material as colluvium. However, the deposits of transported soil are thin and not differentiable from the in-place soil so they were not mapped as a separate unit.

\section{Remaining Sinkhole Slopes}

Continuous outcrops of undulating but generally flat-lying, moderately hard, weak to moderately strong, little weathered, nearly unfractured limestone were observed within the sinkhole along the axis of the drainage that enters the sinkhole from the north and to the southeast along the sinkhole's northeast side. Small parts of the exposed limestone were weathered, weak, 
and loose. We indicate on the geologic maps and cross section (pl. 1) that the limestone is part of the Boone Formation (pl. 1); however, as discussed above, it may be part of the St. Joe Formation. The limestone that comprises the northeast side of the sinkhole overhangs the cave entrance and the cave area immediately downslope from the entrance (pl. 1; Geologic Cross Section). The part of this limestone outcrop that protrudes farthest over the cave entrance is indicated by a heavy red line on the geologic maps (pl. 1). Limestone exposures along the northeast sinkhole slope have surface inclinations of $55^{\circ}$ to overhanging, and most of them are covered with mature-appearing mosses or very thin soil. Soil that averages about one-meter thick and is comprised of gravelly silt is exposed along the top of the northeast slope and was identified in a direct-push hole advanced just northeast of the sinkhole (GS-4, Appendix A and pl. 1; geologic maps).

Two joints cut the limestone exposed in the sinkhole near the north part of the cave entrance. These joints were planar and vertical with an average strike (orientation) of $17^{\circ}$ west of north and generally were tightly closed and unfilled. One of these joints defines the east side of a block failure of the sinkhole wall. This failure created a cavity within the wall up to about 2-m (7 ft) high and 6-m (20 ft) deep (measured from the sinkhole slope face). The area of this failure is delineated on the Geologic Map (pl. 1) by the dashed 296-m topographic contour and the western of the two joints. Broad, low-volume seepage was observed emanating from the limestone wall above the failure. The block that fell now comprises the floor of the void that its displacement created, and the base of the block can be partly observed within Logan Cave where it rests on gravelly soil.

The southeast and northwest sinkhole slopes generally are inclined between $50-55^{\circ}$, although sporadic limestone outcrops were observed along these slopes with vertical surfaces. These bedrock exposures protrude through a very thin (less than $0.3-\mathrm{m}$ (1-ft) thick) mantle of sandy, gravelly soil that covers most of these two slopes. Sparse, immature bushes and trees also occupy the slopes. As identified at the rim of the sinkhole and in direct-push holes advanced to the east (GS-5 and 6, Appendix A and pl. 1), thicker soil mantles bedrock outside of the sinkhole and consists of gravelly silt. The southeast and northwest slopes display scarps to about $0.3-\mathrm{m}$ (1-ft) high that appear to have formed from shallow landsliding (pl. 1; geologic maps). A 2-m (7-ft) -high scarp is located along the base of the northwest slope and likely was created by surface-water erosion. A small amount of rilling was observed extending along the junction of the northeast and southeast slopes and is indicated by the intermittent drainage symbol on the geologic maps (pl. 1). Gravel and organic material has collected along the lower part of this intermittent drainage and within the cave where the drainage changes course toward the northeast (pl. 1; Southwest-Slope Geologic Map).

\section{Logan Cave}

Near the sinkhole entrance, Logan Cave consists of two parts; the lower part of the southwest slope and overhanging limestone bedrock and the tubular limestone passageway (pl. 1;
Geologic Cross Section). Figure 2 shows both of these parts of the cave in a view to the northwest, similar to the view shown in the Geologic Cross Section (pl. 1). Note the soil mantling bedrock in the figure, the green area outside the cave near the upper-left corner of the figure, and the large mound of soil on the floor of the passageway in the lower right part of the figure. Soil locally mantles bedrock on the northeast side of the passageway, as shown in the left center of figure 3 , which is a view to the southeast from within the passageway. A stream runs along the floor of the passageway and beneath the bedrock that comprises the cave's northeast wall as shown on the Geologic Cross Section (pl. 1). The stream appears to flow primarily beneath the bedrock downslope of the cave entrance and primarily along the floor of the passageway both upstream and downstream (southeast and northwest, respectively) from the entrance. A thin (less than 0.5-m (1.6-ft) thick) deposit of sandy gravel generally covers the floor of the passageway, but this deposit is much thicker (over

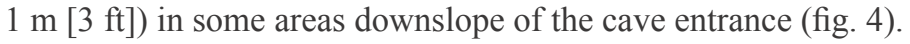
It is our understanding that a 50-year rainfall event occurred during the summer of 2003, after which soil within the cave entrance and passageway was first observed (Carla Mitchell, oral commun., 2004).

Immediately upstream from the entrance, the cave becomes tubular with limestone walls, ceiling and floor (with the exception of soil covering the floor). The cave becomes tubular downstream from the entrance, as well. However, a layer of sandy gravel is exposed along the southwest wall of the cave (fig. 5) between

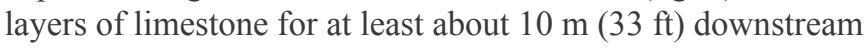
from the entrance (the length of passageway explored during our study). This layer of sandy gravel can be followed through the northern part of the cave entrance where it merges with the sandy, gravelly soil mapped on the southwest slope of the sinkhole.

\section{Laboratory Test Results}

All samples obtained from the direct-push holes were tested for water content. Test results (Appendix B) revealed that water content varied little with depth at each direct-push hole location, and that moisture levels were typical for moist to wet soils. No indication of a nearby water table was observed. Grain-size distribution tests performed on samples obtained from GS-1, GS-2, GS-3, and GS-7 indicated that the soil generally is wellgraded, sandy gravel with little fine-grained material. Atterberg limit tests indicated that the fine-grained parts of these samples consist primarily of low-plasticity silt.

The two tube samples of soil were obtained from just within the cave on the southwest slope (pl. 1; Southwest-Slope Geologic Map). The samples were obtained from this location because the soil appeared to be somewhat fine grained, which is required for performing most strength tests. CTL classified these samples as silt with sand and gravel, which differs from all other samples obtained during our subsurface exploration; therefore, the material in the tube samples is not necessarily representative of the southwest slope as a whole. These samples had a wet unit weight of $14.81 \mathrm{kN} / \mathrm{m}^{3}\left(94.3 \mathrm{lb} / \mathrm{ft}^{3}\right)$ at 22.0 percent moisture content, and a dry unit weight of $12.14 \mathrm{kN} / \mathrm{m}^{3}\left(77.3 \mathrm{lb} / \mathrm{ft}^{3}\right)$. These 

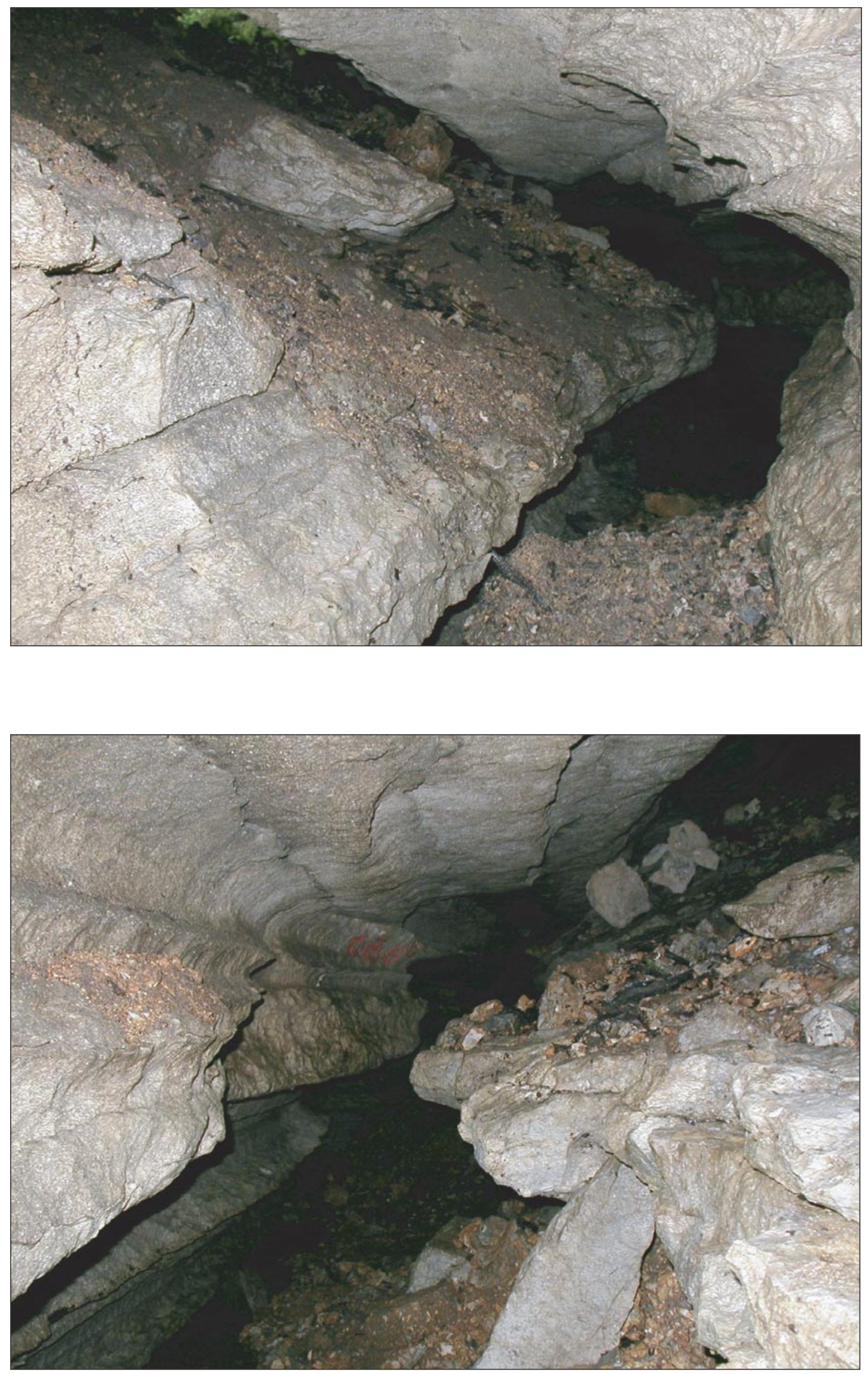

Figure 2. Photograph of the passageway and sinkhole entrance to Logan Cave. View is to the northwest. Passageway is at right, entrance is visible near the upper left (light green vegetation outside of the cave is visible), and sandy gravel and other debris is visible draping most of the slope from the entrance to the passageway and on the floor of the passageway. The width of the passageway at the bottom of the photograph is about one meter.

Figure 3. Photograph of the passageway (center of view) and part of the sinkhole entrance (right side of view) to Logan Cave. View is to the southeast. Sediment on the northeast wall of the cave is visible in the left center, as well as on the southwest slope (upper right) and passageway floor. Height of the passageway in the photograph is about two meters. 

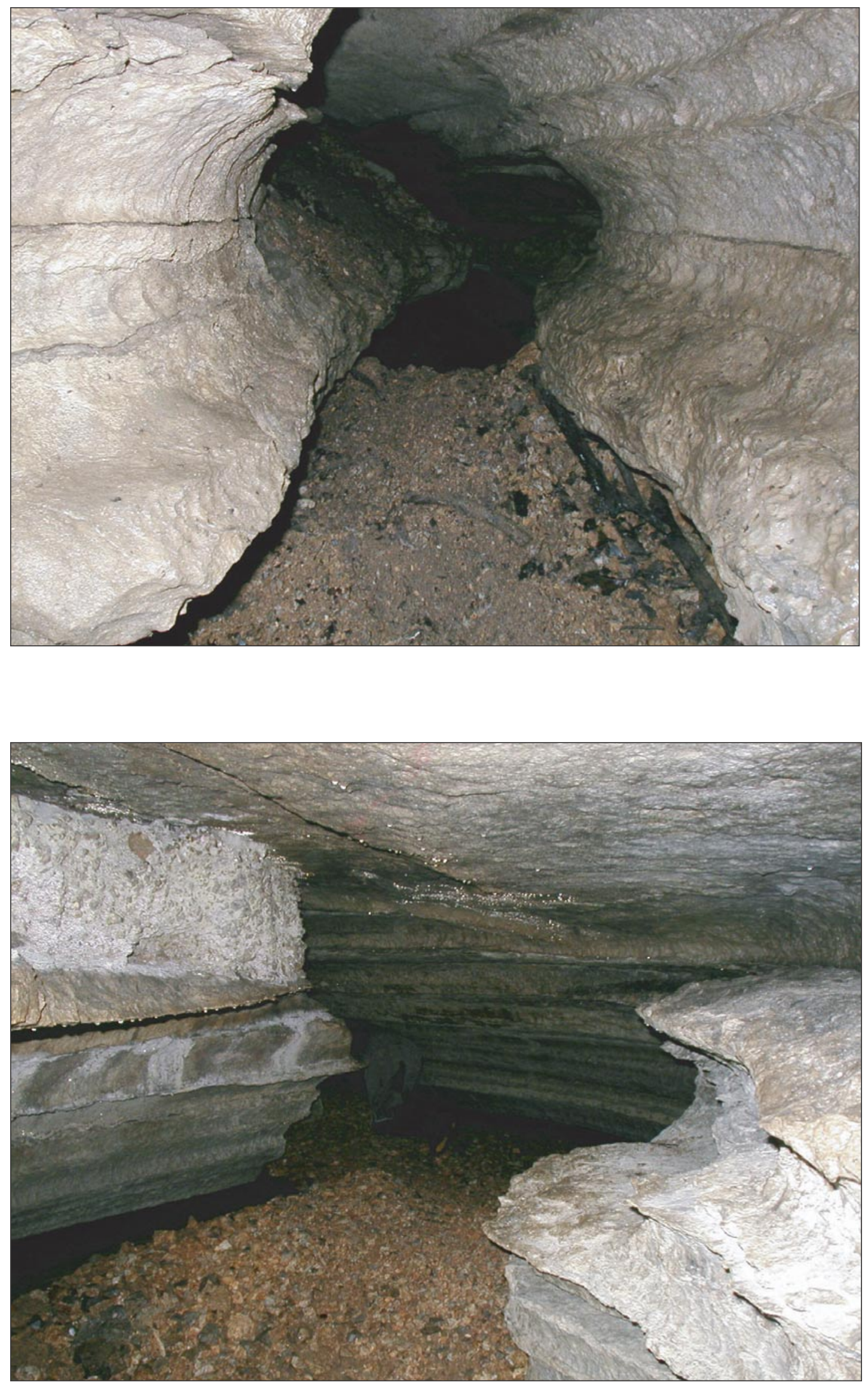

Figure 4. Photograph of the passageway from southeast of the sinkhole entrance showing a thick accumulation of sediment on the floor of the passageway. View is to the northwest. The entrance is to the left and upslope of this accumulation. Passageway is about 2-meters wide at its widest point in this photograph.

Figure 5. Photograph of the passageway northwest of the sinkhole entrance. View is to the northwest. Sandy gravel deposits between layers of limestone are visible on the left extending down from the roof of the passageway. Height of the passageway is about $1.5 \mathrm{~m}$. 
unit weight values are typical for sandy gravel, as well (Das, 1994, p. 44). Triaxial-compressive-strength tests performed on these samples indicated total and effective friction angles of $24.9^{\circ}$ and $36.3^{\circ}$, respectively, and no cohesion. These friction angle values should be considered lower bounds since the triaxial test was performed in multiple stages, and the sample was remolded, both of which tend to reduce strength test results (for example, Lambe and Whitman, 1969; Terzaghi and others, 1996).

\section{Slope-Stability Analysis}

No evidence of large-scale instability was identified along the southwest slope of the sinkhole; however, evidence of shallow (less than 0.3-m (1-ft) deep) landsliding and raveling was observed. The average inclination of this slope is $47^{\circ}$, which is quite steep for a slope comprised of gravel. Therefore, we performed stability analysis of the southwest slope using Version 7 of the finite-element program PLAXIS ${ }^{\odot}$. This program was developed specifically for geotechnical analysis, such as slope-stability analysis, and has been demonstrated to provide similar results to those of conventional slip-circle slope-stability analyses, yet it does not require predetermination of failuresurface geometry or special assumptions about interslice forces as do the slip-circle techniques (Griffiths and Lane, 1999; Savage and others, 2000).

We analyzed stability of the southwest slope as it is shown on the Geologic Cross Section (pl. 1). PLAXIS $^{\odot}$ requires input of the soil unit weight, Young's modulus, Poisson's ratio, angle of internal friction $(\phi)$, and cohesion $(c)$. Of these, slopestability analyses generally are most sensitive to variations of the strength properties $\phi$ and $c$. We used soil parameter values that were determined in the laboratory and selected from published literature.

The triaxial-compressive-strength test provided soil strength parameters of $\phi=24.9^{\circ}$ and $c=0$ for the soil on the lower part of the southwest slope. As stated previously, the material that was tested to obtain these parameters is not representative of the majority of the material that comprises the southwest slope. We assumed that $\phi=24.9^{\circ}$ represents a lower bound for the soil that comprises the slope, and that the soil must have some cohesion because the slope is currently stable. As an upper bound for the strength parameters, we chose a friction angle of $48^{\circ}$, which is a published value for angular gravel with some sand (Das, 1994, p. 320). The soil that comprises the southwest slope is well characterized as angular gravel with some sand, so this friction angle probably is more representative than the lower value from laboratory tests. Young's modulus and Poisson's ratio were held at constant values of $60,000 \mathrm{kN} / \mathrm{m}^{2}\left(1.2 \times 10^{6} \mathrm{lbf} / \mathrm{ft}^{2}\right)$ and 0.4 , respectively, which fall in the range of published values obtained from several sources (Lambe and Whitman, 1969, p. 159; Das, 1994, p. 301). Unsaturated unit weight was determined in the laboratory to be $14.81 \mathrm{kN} / \mathrm{m}^{3}\left(94.3 \mathrm{lb} / \mathrm{ft}^{3}\right)$. We increased the unsaturated unit weight to $17 \mathrm{kN} / \mathrm{m}^{3}\left(108 \mathrm{lb} / \mathrm{ft}^{3}\right)$ during analyses, which is near the unit weight of the soil at saturation $\left(17.52 \mathrm{kN} / \mathrm{m}^{3}\left[111.6 \mathrm{lb} / \mathrm{ft}^{3}\right]\right)$ based on calculations made using laboratory test results.
The southwest sinkhole slope appeared to be stable at the time of our field investigation. Based on the geometry of the slope and the potential strength of the soil of which it is comprised, we assumed that the slope is marginally stable. Our stability analyses was designed to determine likely failure geometries and the degree of soil-parameter variability required to result in slope failure. Failure of the slope could occur due to changes in strength or loading conditions, both of which could vary due to changes in moisture content in the slope following prolonged rainfall. It is unlikely that ground water exists in the slope at depths that could affect its stability because none was observed during our field investigation, soil likely extends to depths significantly below the slope face due to the origin of the soil deposit (discussed in the Conclusions section), and the regional water table has been mapped at $23 \mathrm{~m}(75 \mathrm{ft})$ below the sinkhole entrance (Ogden, 1980). Therefore, increasing porewater pressures within the soil due to increasing ground-water levels are not expected to occur and thus slope failure by this mechanism is unlikely.

We analyzed the slope with two strength scenarios and two unit weight scenarios. Strength of the soil that comprises the slope primarily is derived from friction, since granular soils generally have very little cohesive strength. However, apparent cohesion due to capillary forces exerted by water held within the soil matrix may contribute significantly to the strength of the slope (Wu, 1996), and is not readily measured during strength testing (Lu and Likos, 2004). This capillary cohesion varies nonlinearly with water content and is reduced to zero as the soil dries completely or reaches saturation. We used the upper and lower bound friction angles obtained from the laboratory and literature to calculate the minimum cohesion required for the slope to be stable and then evaluated whether capillary cohesion could exceed this minimum. We also analyzed variable unit weight scenarios to evaluate the effects of rainfall increasing the soil unit weight.

\section{Trial 1-Upper-Bound Angle of Internal Friction- In-Situ Unit Weight}

We analyzed the southwest slope with constant $\phi=48^{\circ}$ and unit weight of $14.81 \mathrm{kN} / \mathrm{m}^{3}\left(94.3 \mathrm{lb} / \mathrm{ft}^{3}\right)$, and varied $c$ until we obtained results of marginal stability. Cohesion of at least $0.7 \mathrm{kN} / \mathrm{m}^{2}\left(14.6 \mathrm{lbf} / \mathrm{ft}^{2}\right)$ was required to provide stability to the slope. This value of $c$ is quite low and is within the likely range of capillary cohesion for this soil type (Lu and Likos, 2004). Figure 6 shows the modeled slope geometry, which matches that of the Geologic Cross Section (pl. 1), and the distribution of stresses predicted by PLAXIS ${ }^{\odot}$. The warm colors indicate high shear stress, while the cool colors indicate low shear stress. Figure 6 indicates that the highest shear stresses, and thus the base of failure predicted if soil strength falls below the modeled values, are concentrated at shallow depth in the upper one-half of the slope. The predicted slope failure has a thickness of about $1.5 \mathrm{~m}$ (4.9 ft) (measured normal to the slope) and is classified as a translational failure, meaning that landslide displacement is parallel to the slope. 


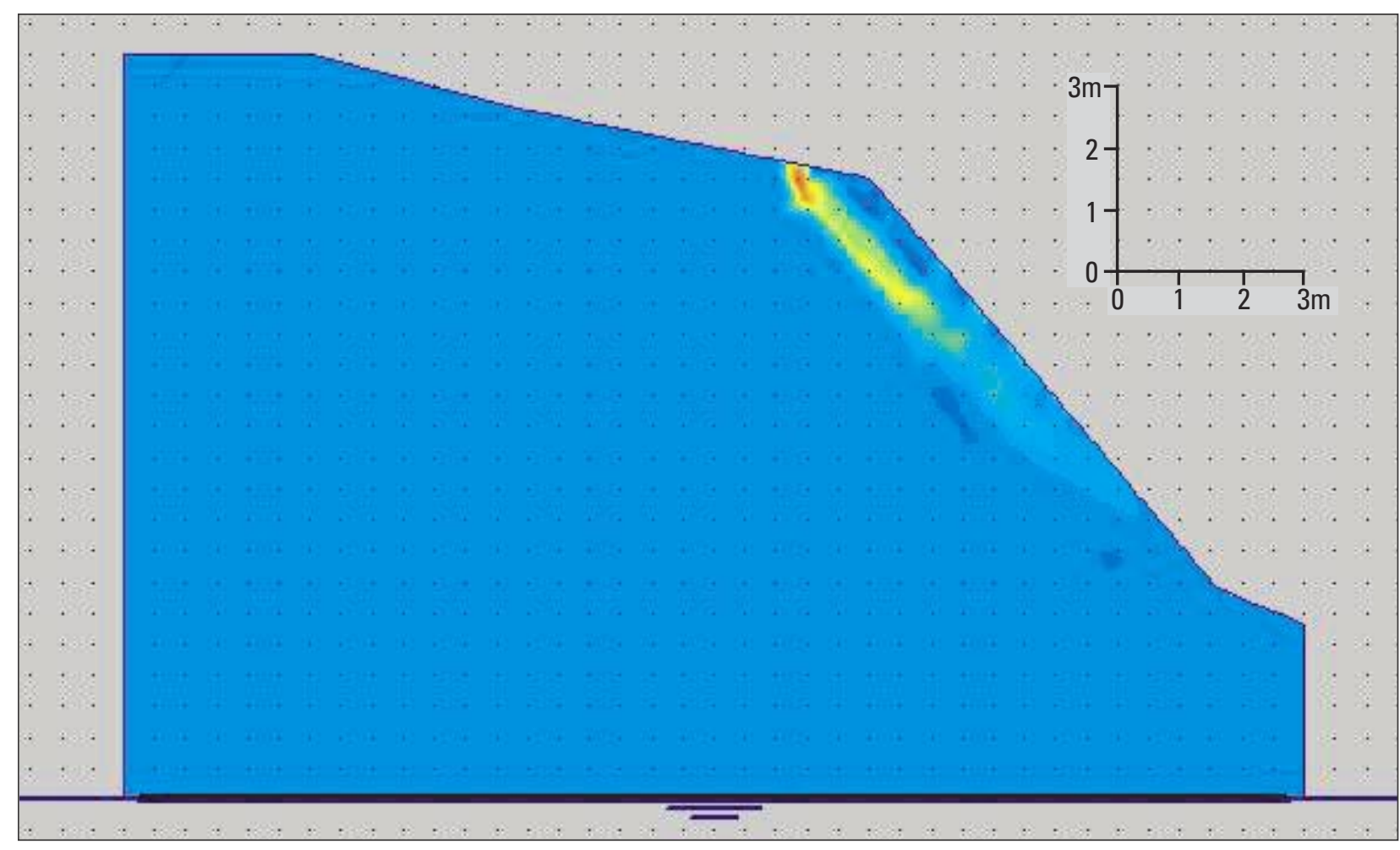

Figure 6. Graphical representation of the Trial 1 slope-stability analysis results showing the modeled southwest slope cross section and calculated stresses. The shear stress field is represented by colors with cool colors indicating low shear stress and warm colors indicating high shear stress. The base of a landslide predicted by this trial would be located where shear stresses are highest (warmest colors).

\section{Trial 2-Upper-Bound Angle of Internal Friction- Saturated Unit Weight}

To model the slope of Trial 1 under nearly saturated conditions, may occur due to heavy rainfall, we increased the unit weight to the nearly saturated unit weight estimated to be $17 \mathrm{kN} / \mathrm{m}^{3}\left(108 \mathrm{lb} / \mathrm{ft}^{3}\right)$ and held $\phi$ and $c$ constant at $48^{\circ}$ and $0.7 \mathrm{kN} / \mathrm{m}^{2}\left(14.6 \mathrm{lbf} / \mathrm{ft}^{2}\right)$, respectively. The analysis indicated that the slope is slightly less stable than for the scenario using the insitu unit weight (Trial 1), but still indicated a marginally stable slope. This result was expected because unit weight has little effect on the analysis as cohesion approaches zero.

\section{Trial 3-Lower-Bound Angle of Internal Friction- In-Situ Unit Weight}

We modeled the southwest slope with constant $\phi=24.9^{\circ}$ and unit weight of $14.81 \mathrm{kN} / \mathrm{m}^{3}\left(94.3 \mathrm{lb} / \mathrm{ft}^{3}\right)$, and varied cohesion to determine the minimum required for stability. We found that $c$ of at least $6.0 \mathrm{kN} / \mathrm{m}^{2}\left(125.3 \mathrm{lbf} / \mathrm{ft}^{2}\right)$ is required for the slope to be stable. As with Trial 1, capillary cohesion of this magnitude is reasonable for the type of soil that underlies the southwest slope. However, the failure predicted to occur if soil strengths drop below the values used during Trial 3 (fig. 7) is much deeper than that predicted during Trial 1. This failure is as deep as $3.5 \mathrm{~m}$ $(11.5 \mathrm{ft})$ (measured normal to the slope), extends to the toe of the slope, and extends back about $4 \mathrm{~m}$ (13 ft) from the sinkhole edge. It is classified as a rotational failure, meaning landslide displacement would involve rotation along a concave-upward failure surface.

\section{Trial 4-Lower-Bound Angle of Internal Friction- Saturated Unit Weight}

The slope of Trial 3 was modeled with the soil nearly saturated, such as may occur due to heavy rainfall, by increasing the unit weight to the estimated near-saturation value of $17 \mathrm{kN} / \mathrm{m}^{3}$ $\left(108 \mathrm{lb} / \mathrm{ft}^{3}\right)$. The strength parameters $\phi$ and $c$ were held constant at $24.9^{\circ}$ and $6.0 \mathrm{kN} / \mathrm{m}^{2}\left(125.3 \mathrm{lbf} / \mathrm{ft}^{2}\right)$, respectively. The analysis indicated that the slope would fail under these conditions. The failure geometry is nearly identical to that shown in figure 7.

\section{Summary of Slope-Stability Analyses}

The conditions modeled as Trials 1 and 2 are likely to more accurately represent potential conditions of the southwest slope than the conditions modeled in Trials 3 and 4; thus, the results of Trials 1 and 2 are more likely representative of potential instability of the southwest slope. This is mainly because the strength parameters used for Trials 1 and 2 are representative of the soil identified nearly everywhere on and within the southwest slope. The soil on which triaxial-compressive-strength tests were 


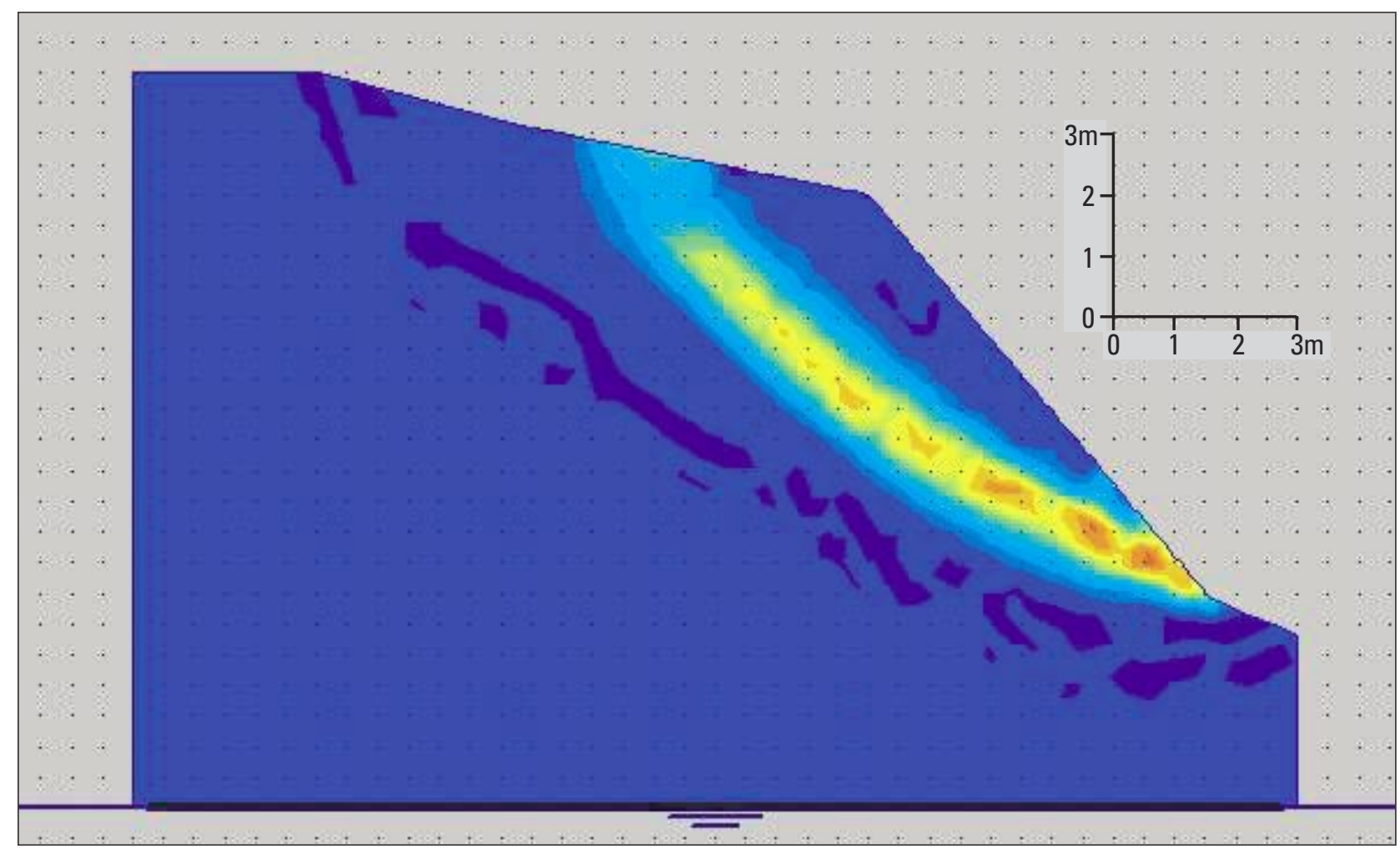

Figure 7. Graphical representation of the Trial 3 slope-stability analysis results showing the modeled southwest slope cross section and calculated stresses. The shear stress field is represented by colors with cool colors indicating low shear stress and warm colors indicating high shear stress. The base of a landslide predicted by this trial would be located where shear stresses are highest (warmest colors).

performed was generally not representative of the soil observed on and within the southwest slope. Slope failures predicted by Trials 1 and 2 were thin (about 1.5-m (4.9-ft) thick) and occurred on about the upper one-half of the southwest slope. Failure of the slope would most likely occur during or following significant rainfall events due to a decrease in capillary cohesion.

It is our opinion that the southwest slope is marginally stable, given realistic strength parameters and the slope geometry. Therefore, eventual failure of the slope seems likely. The likelihood of slope failure is greatest during intense rainfall on already wet soil. It is worth noting that the 50 -year storm of 2003 did not trigger large-scale landsliding, but did trigger small-scale landsliding and transport of soil into the cave entrance.

\section{CONCLUDING DISCUSSION}

The sinkhole entrance to Logan Cave is a geologically active environment and should continue to be so in the future. Our investigation indicated that several geologic processes have been changing the sinkhole entrance for many years. An important aspect in predicting future evolution of the sinkhole entrance is understanding what has happened in the past.

\section{Geologic History}

The sinkhole entrance to Logan Cave is located along and to the east of the axis of a drainage that probably was created during the Pleistocene epoch $(1,800,000-10,000$ years ago; Manger and others, 1988b). Our investigation revealed that a sinkhole larger than that which currently provides the entrance to Logan Cave extended to the southwest and has been filled with sandy, gravelly soil that we conclude is alluvium (pl. 1). This sinkhole must have formed prior to or during the Pleistocene to have filled with alluvium. As a result of the previous sinkhole being filled with alluvium, the southwest slope of the current sinkhole is underlain by alluvium. No surface expression was observed of the larger, older sinkhole, other than, perhaps, the general broadening of the drainage valley in this area. The large block failure located adjacent to the north end of the present cave entrance rests on alluvium, indicating that the failure occurred while the original sinkhole was filling.

While the previous sinkhole filled (or after it filled), sediment was transported by surface water and shallow slope failures into the present entrance of Logan Cave and also into a similar adjacent entrance located to the northwest. This entrance completely filled with sediment as evidenced by the sandy gravel exposures in the southwest wall of the passageway northwest of the present entrance (fig. 5 and pl. 1; Southwest-Slope Geologic 
Map). The former entrance probably was a solution channel that was exposed in the walls of the previous sinkhole. Sediment fills the former entrance completely and must have partly filled the passageway because the deposit displays a vertical, erosional surface within the cave. This indicates that the stream was capable of transporting sediment from the passageway in the past, but not from the former entrance. There also is evidence of stream transport of sediment immediately downslope of the present entrance. Figure 2 provides a view to the southeast of the present entrance area and passageway and shows a large mound of sediment blocking the floor of the passageway as well as a small amount of sediment high on the northeast wall of the passageway (left side of figure). This sediment on the northeast wall seems to indicate that a thick deposit previously existed at this location but was subsequently removed by the stream. The ages of this deposit and subsequent removal, however, are unknown. At present, the stream in the entrance area flows almost entirely beneath the northeast wall of the passageway, thus it appears to no longer be capable of removing sediment deposited downslope of the entrance. In fact, the stream is not visible at all near the mound of sediment shown in figure 2; it flows completely beneath the northeast bedrock wall. Many episodes of sediment deposition in the passageway likely have resulted in accelerated dissolution of the northeast wall, thus the stream has migrated to the northeast away from the entrance. Even if the stream is capable of flushing sediment from the passageway in the future, that may not prevent the entrance from closing, as occurred at the former entrance located to the northwest.

\section{Mechanisms of Sedimentation Within the Sinkhole Entrance}

Observations made by cave researchers during the past several decades have indicated that the sinkhole entrance to Logan Cave is progressively filling with sediment. As discussed above, the stream within Logan Cave probably has removed significant volumes of sediment in the past, but did not prohibit a former entrance from filling. In addition, the stream has migrated away from the passageway in the cave entrance area so probably is no longer capable of removing sediment and keeping even the passageway open. There are several mechanisms responsible for transporting sediment into the cave entrance that could be mitigated to keep the entrance open. These mechanisms include foot traffic, surface-water flow, and landsliding.

\section{Foot Traffic}

Scientists and others have used the sinkhole entrance to gain access to Logan Cave for at least the past 50 years and continue to do so (David Kampwerth, oral commun., 2004). A trail within the sinkhole has been used to access the cave entrance. Foot traffic on this trail has moved alluvium downslope and has created a large, deep gully through the sinkhole rim near the south end of the southwest slope (pl. 1; geologic maps). Much of the transported sand and gravel has accumulated near the cave entrance as indicated by the decreased slope in this area, and a significant amount has accumulated within the cave entrance and passageway. By reconstructing the pre-gully topography of the sinkhole, we calculate that just over $10 \mathrm{~m}^{3}\left(350 \mathrm{ft}^{3}\right)$ of sediment has been transported by foot traffic. This volume is sufficient to fill about 80 percent of the passageway located downslope of the sinkhole entrance. Transport and deposition of this sediment has been very gradual and probably permitted much of the material that traveled as far as the passageway to be removed by the stream. However, with the reduced sediment transport capacity of the stream, gravel pushed downslope into the cave likely will no longer be removed. The loose nature of the alluvium and steep inclination of the trail will result in continuing transport of sediment into the cave by foot traffic, based on our own experience and observations.

\section{Surface-Water Flow}

Alluvium and the soil that mantles bedrock, which we conclude is regolith (pl. 1), are prone to erosion and transport to the cave by surface-water flow due to their low density and lack of cohesive strength. The 50-year rainfall event of 2003 demonstrated the capability of surface water to transport sediment to the cave. Surface-water flow occurs as sheet flow and concentrated flow. Sheet flow occurs on all slopes and primarily transports and deposits fine-grained soil. Concentrated flow occurs in some areas, especially within the drainage that enters the sinkhole from the north, near the junction of the northeast and southeast slopes, and down the access trail. Concentrated flow in these areas has resulted in more pronounced erosion than that due to sheet flow as well as transport and deposition of up to cobble-sized rocks. Surface-water flow within the sinkhole is due to precipitation falling in the sinkhole and overland flow down the north drainage and the slopes above the northeast side of the sinkhole. Overland flow from the slope above the northeast side of the sinkhole appears to occur both on the ground surface and within the regolith with water perched at its base on top of limestone bedrock. This transient ground water seeps out of the regolith where it encounters the sinkhole slopes and then flows as surface water within the sinkhole.

\section{Landsliding}

Shallow (less than $0.3-\mathrm{m}$ (1-ft) thick) landsliding seems to be an ongoing process within the sinkhole, especially along the upper parts of the slopes and in the shallow regolith mantling parts of the bedrock slopes. Much of this landsliding seems to have been associated with surface-water erosion as the landslide scars are adjacent to erosional gullies. Scarps shown on the geologic maps on the southeast slope probably were formed by small, shallow landslides. No evidence was observed for largescale landsliding within the sinkhole. As discussed in the SlopeStability Analysis Section, reasonable strength parameters for the alluvium indicate that the slope currently is in a condition of marginal stability. Future landslides would most likely be triggered by prolonged, heavy rainfall. These landslides would be shallow (up to about 1.5-m (4.9-ft) thick), translational failures of the upper part of the southwest slope, as well as much smaller landslides from the very shallow regolith mantling bedrock 
along the other sinkhole slopes. Slope failures smaller than those predicted by our slope-stability analysis probably occurred during the 50-year rainfall event of 2003 and resulted in deposition of a large volume of alluvium in the cave entrance and passageway. However, larger landslides did not occur during that rainfall event. It is possible that future heavy rainfall may trigger larger failures that could result in complete closure of the cave entrance. We believe that landslides of this magnitude are unlikely to occur, and that small, shallow landslides are very likely in the future, several of which could result in closure of the cave entrance.

Evaluation of the stability of the sinkhole slopes that are comprised of bedrock was beyond the scope of our study. There is a large amount of rock cantilevered over the cave entrance as illustrated on the Geologic Cross Section (pl. 1). However, discontinuities (other than bedding planes) along which failure of this rock mass could occur were not observed, although they may exist farther into the slope. As described earlier, a large wedge of rock failed just northwest of the cave entrance while the previous sinkhole filled with alluvium, and scattered deposits of other rock falls are visible low on the southwest slope. Failure of a bedrock slope within the sinkhole would likely be triggered by exceptionally heavy precipitation or additional undercutting by the stream located within the cave.

\section{Summary of Sedimentation Mechanisms}

Other than foot traffic, the mechanisms responsible for transporting sediment into the sinkhole entrance of Logan Cave cannot feasibly be eliminated. Sediment will continue to be transported by surface-water flow and landslides, as well as by foot traffic when it occurs. The stream within the cave passageway downslope of the entrance is no longer capable of flushing sediment from this area. Thus, it is our opinion that the sinkhole entrance eventually will fill with sediment, eliminating this point of access to the cave for scientists and other animals, including the endangered gray bat. The potential for sudden, complete closure of the entrance due to a large landslide is probably remote, but it does exist.

\section{Mitigation Alternatives}

Many alternatives exist to reduce the amount of sedimentation within the sinkhole entrance to Logan Cave. However, the potential impact of any mitigation measures on species that reside within the cave must be considered along with cost, disturbance of the natural environment outside of the cave, safety of cave researchers, and other issues. Also, it should be considered that construction-related activities could result in significant disruption of the cave ecosystem. Provided below are some alternatives to reduce the amount of sedimentation in the cave and the potential for slope failure to close the sinkhole entrance. These alternatives are provided in order of increasing cost associated with their construction and the degree of disturbance of the natural environment that they involve. Different combinations of the mitigation measures than those provided below for each alternative could be used as well.

\section{Alternative 1-Periodic Sediment Removal}

Approximately $10 \mathrm{~m}^{3}\left(350 \mathrm{ft}^{3}\right)$ of sediment mantles bedrock within the cave entrance and the passageway downslope. This sediment reduces the size of the entrance and passageway, thus increasing the potential for the entrance or passageway to be blocked. Loose sediment could be manually excavated in the cave and transported from the sinkhole. Manual excavation and transport could be performed relatively quickly with the assistance of a cable-and-pulley system from the cave entrance to south of the sinkhole that would allow containers filled with sediment to be rapidly transported out of the sinkhole, emptied, and returned to the cave entrance without requiring significant foot traffic into and out of the sinkhole. This alternative does not address mechanisms responsible for transporting sediment to the cave so would need to be performed periodically. It does not directly address the potential for the cave entrance to be closed by sedimentation (other than by providing space into which sediment may be deposited).

\section{Alternative 2-Foot-Traffic Erosion Control and Periodic Sediment Removal}

Foot traffic along the trail that traverses the southwest slope of the sinkhole and leads to the cave entrance has resulted in transport of about $10 \mathrm{~m}^{3}\left(350 \mathrm{ft}^{3}\right)$ of alluvium from along the trail to the lower parts of the slope and within the cave. Placement of a cellular paver, geogrid, or geotextile fabric along the trail that is designed to reduce erosion of granular soils by foot traffic and surface water, such as those described at http://www.ndspro.com/, would greatly reduce the amount of sediment transported by foot traffic. Improvement of the trail would not address future sedimentation within the cave by landsliding or surface-water transport. To address sedimentation from these processes, sediment could be periodically excavated and removed from the cave passageway and entrance areas by hand as described under Alternative 1.

\section{Alternative 3-Sediment-Retention Wall, Foot-Traffic Erosion Control, and Periodic Sediment Removal}

This alternative addresses some of the limitations of Alternative 2 by nearly eliminating the potential for sediment to enter the sinkhole entrance by any mechanism. Sediment transported downslope could be retained by a wall constructed just southwest of the cave entrance as close to the overhanging cliff as possible, yet far enough away to allow access to the entrance. The wall should be about 1-m (3-ft) high and abut the cliff just beyond the ends of the entrance. The wall could be constructed of pressure-treated lumber secured to posts set in concrete in holes drilled or excavated to sufficient depth to support the wall and a full load of alluvium. Alternatively, the wall could be constructed of formed, steel-reinforced concrete upon a footing cantilevered into the slope. A concrete wall would simplify maintenance (described below) and would not have the potential adverse effects on organisms within the cave that pressure-treated lumber may have. Any wall constructed 
should be designed by a registered civil engineer using the soil parameters of $c=0, \phi=47^{\circ}$, unit weight of $17.5 \mathrm{kN} / \mathrm{m}^{3}\left(111 \mathrm{lb} / \mathrm{ft}^{3}\right)$, and a frost-penetration depth of $0.51 \mathrm{~m}$ (20 in.) (Naval Facilities Engineering Command, 1986). Drainage holes should not be necessary through the wall as the alluvium drains effectively and is unsaturated. Note that special precautions must be taken to construct a wall without adversely affecting the slope during construction. These precautions are described in Construction Notes below.

Erosion by foot traffic should be addressed as described under Alternative 2. Although a wall would retain material transported by foot traffic, the cost of foot-traffic erosion control measures is relatively small, and their benefits are high. Foot-traffic erosion control measures would greatly reduce the need for periodic maintenance at the sediment-retention wall and would enhance the stability of the southwest slope near the trail.

The sediment-retention wall and foot-traffic erosion-control measures would greatly reduce the volume of sediment transported into the cave entrance. However, the height of the wall must be maintained by periodic removal of sediment from against the wall to reduce the likelihood of sediment overtopping the wall. Removal of sediment from within the cave should only be necessary following wall construction if the wall is overtopped, which is extremely unlikely if maximum wall height is maintained. If a lumber wall is constructed, it must be periodically inspected for rotted, damaged, loose, or otherwise flawed lumber in accordance with manufacturer's specifications. Flawed lumber must be replaced in accordance with wall designs.

\section{Alternative 4-Slope Excavation, Foot-Traffic Erosion Control, and Periodic Sediment Removal}

This alternative provides measures to significantly reduce the amount of alluvium entering the cave from the southwest slope by reducing the potential for mobilization of the alluvium. The alternative does not address sediment input to the cave from other slopes, however. The likelihood of landsliding to occur on the southwest slope and mobilization of alluvium by surface water could be greatly reduced by excavating the southwest slope such that a consistent slope angle of no greater than $38^{\circ}$ is attained. Excavation of the slope should be planned and executed such that smooth transitions are made between the southwest and adjacent slopes, which would require partial excavation of those slopes. This alternative likely would result in temporarily increased surface-water transport of sediment to the cave from the transition areas between the southwest slope and adjacent slopes. Following excavation of the southwest slope, foot-traffic erosioncontrol measures described in Alternative 2 should be constructed to reduce the potential for future transport of sediment by foot traffic. Because Alternative 4 does not address sedimentation from sources other than the southwest slope, and because some alluvium would continue to be transported down the southwest slope to the cave, periodic removal of sediment from the cave entrance would be necessary, as described under Alternative 1 .

\section{Construction Notes}

Construction of any measures within the sinkhole must be carefully designed and implemented to reduce potential impacts to the cave and its inhabitants. Temporary debris catchment/ retention structures should be constructed outside of the cave entrance prior to construction activities. These could entail sturdy lumber or sheet metal sections braced across the cave entrance if larger failures are anticipated (such as during excavation for a wall or of the entire southwest slope), or silt fencing along the slope just above the cave entrance if only transport due to foot traffic is anticipated (such as during placement of foot-traffic erosion-control measures or manual excavation of sediment from within the cave entrance). If a concrete wall is constructed, excavation of the southwest slope to permit construction of the footing and wall must be performed in steps so that no more than $3 \mathrm{~m}$ of slope (measured along topographic contour) is unsupported at any one time to reduce the total size of potential slope failures during construction. We expect that any significant depth of excavation (such as to frost depth) will result in small failures of the slope near the excavation. These failures must be anticipated, and preparations must be made to accommodate them.

We observed that gravel-sized and smaller rock fragments primarily comprise the southwest slope. However, large blocks of rock (greater than 1-m (3-ft) diameter) were also observed on this slope, mainly along the lower part. Isolated, large blocks of rock probably would be encountered during excavation of the lower part of the southwest slope and should be accounted for on any construction drawings or specifications.

Any material removed from the sinkhole (rock, soil, and organic debris) could be placed within the refuge in an environmentally-sound location approved by USFWS personnel. However, at no time should excavated material be placed closer

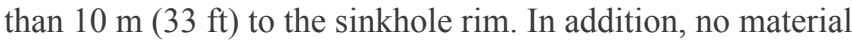
should be placed north or east of the sinkhole or within the southtrending intermittent drainage.

\section{Summary of Mitigation Alternatives}

In our opinion, the most cost-effective and least-disruptive alternative to reduce the potential for closure of the sinkhole entrance to Logan Cave is Alternative 3, because this alternative requires little disruption within the sinkhole (compared to Alternative 4) and will allow the cave entrance to remain at least partly open following all but the largest (and least likely) landslides on the southwest slope. Alternative 3 also would significantly reduce sediment input to the cave from other areas of the sinkhole. Alternative 4 reduces the potential for landslide events, but does not address transport of soil from slopes other than the southwest and requires significant disturbance within the sinkhole. Alternatives 1 and 2 do not address the potential for large landslides to close the sinkhole entrance, other than by providing void space into which landslide debris may be deposited. 
We believe the potential for sudden closure of the entrance due to landsliding of the southwest slope is extremely small if Alternative 3 or 4 is implemented. However, the results could be catastrophic if such a closure occurred while scientists (or others) occupied the cave. It is our opinion that the cave should not be occupied during or within several days following abnormally heavy, prolonged rainfall events. In addition, the alternatives provided herein do not address failure of the rock slopes that comprise the other sides of the sinkhole, although the sedimentretention wall of Alternative 3 should provide some protection to the cave entrance should failure of these other slopes occur.

\section{REFERENCES CITED}

American Society for Testing and Materials, 2002, Annual book of ASTM Standards: Philadelphia, Pa., American Society for Testing and Materials, v. 4.08, $1672 \mathrm{p}$.

Bartholmey, E.C., Martin, J.W., Kresse, T.M., and Brahana, J.V., 1995, Influence of fractures and faults on the hydrogeology of springs of the Springfield Plateau in northwestern Arkansas [abs.]: Geological Society of America Abstracts with Programs, v. 27, no. 6, p. A-100.

Bostian, Rick, and Brahana, J.V., 1996, Regional tectonic and structural control on the hydrogeology of the Boone-St. Joe aquifer, northwest Arkansas [abs.]: Geological Society of America Abstracts with Programs, v. 28, no. 1, p. 5-6.

Das, B.M., 1994, Principles of geotechnical engineering: Boston, Mass., PWS Publishing Company, 672 p.

Goodman, W.M., and Mack, L.E., 1985, Anomalous hydraulic behavior of the Boone-St. Joe limestone aquifer, northwest Arkansas [abs.]: Geological Society of America Abstracts with Programs, v. 17, no. 3, p. 160.

Griffiths, D.V., and Lane, P.A., 1999, Slope stability analysis by finite elements: Geotechnique, v. 49, no. 3, p. 387-403.

Guccione, M.J., and Rieper, Barbara, 1988, Late Quaternary history of the White River, Fayetteville, Arkansas: The Compass, v. 65, no. 4, p. 199-206.

Haley, B.R., 1993, Geologic map of Arkansas: U.S. Geological Survey, 1:500,000.

Lambe, T.W., and Whitman, R.V., 1969, Soil mechanics, New York, John Wiley \& Sons, Inc., $553 \mathrm{p}$.

Lu, Ning, and Likos, W.J., 2004, Unsaturated soil mechanics: Hoboken, N.J., John Wiley \& Sons, Inc., 556 p.

Manger, W.L., Shelby, P.R., and Farris, S.G., 1988a, DevonianLower Mississippian lithostratigraphy, northwestern Arkansas: The Compass, v. 65, no. 4, p. 223-231.
Manger, W.L., Zachry, D.L., and Garrigan, M.L., 1988b, An introduction to the geology of northwestern Arkansas: Field trips: The Compass, v. 65 , no. 4, p. 242-256.

Martin, J.W., 1994, Structural features as a control of groundwater flow in the Boone-St. Joe aquifer in northwestern Arkansas [abs.]: Geological Society of America Abstracts with Programs, v. 26, no. 1, p. 23.

Martin, J.W., and Brahana, J.V., 1995, Comparative hydrogeology of large springs of the Springfield Plateau in northwestern Arkansas [abs.]: Geological Society of America Abstracts with Programs, v. 27, no. 6, p. A-181.

Naval Facilities Engineering Command, 1986, Soil mechanics, Design Manual 7.01: Alexandria, Va., Naval Facilities Engineering Command, 348 p.

Ogden, A.E., 1980, Hydrogeologic and geochemical investigation of the Boone-St. Joe limestone aquifer in Benton County, Arkansas: Arkansas Water Resources Research Center, University of Arkansas Publication No. 68, 133 p.

Rezaie, M.N., Ogden, A.E., and Willis, W.H., 1979, Aquifer characteristics of the Boone-St. Joe aquifer in northwest Arkansas [abs.]: Geological Society of America Abstracts with Programs, v. 11, no. 2, p. 165.

Savage, W.Z., Baum, R.L., Morrissey, M.M., and Arndt, B.P., 2000, Finite element analysis of the Woodway Landslide, Washington: U.S. Geological Survey Bulletin 2180, 9 p.

Smith, S.D., 1994, Seasonal variability of ground-water quality and transport processes near active landfills in northwestern Arkansas [abs.]: Geological Society of America Abstracts with Programs, v. 26, no. 1, p. 27.

Stanton, G.P., 1994, Processes and controls affecting anisotropic flow in the Boone-St. Joe aquifer in northwestern Arkansas [abs.]: Geological Society of America Abstracts with Programs, v. 26, no. 1, p. 27.

Terzaghi, Karl, Peck, R.B., and Mesri, Gholamreza, 1996, Soil mechanics in engineering practice: New York, John Wiley \& Sons, Inc., 549 p.

United States Department of Agriculture, Soil Conservation Service, 1977, Soil survey of Benton County, Arkansas: U.S. Department of Agriculture, Soil Conservation Service, $87 \mathrm{p}$.

Wu, T.H., 1996, Soil strength properties and their measurement: in Turner, A.K. and Schuster, R.L., eds., Landslides, Investigation and Mitigation, Transportation Research Board Special Report 247: Washington, D.C., National Research Council, p. 319-336. 
APPENDIX A

Logs of Subsurface Exploration 


\section{U.S. GEOLOGICAL SURVEY LANDSLIDE HAZARDS PROJECT LOG OF SUBSURFACE EXPLORATION}

Project__Logan Cave

Borehole/Probehole Name

GS-1

Location_South of sinkhole

Date

July 27-28, 2004

Exploration Equipment_Geoprobe macro-core (0.6-m long), electric hammer

Geologist_Bill Schulz/Jon McKenna

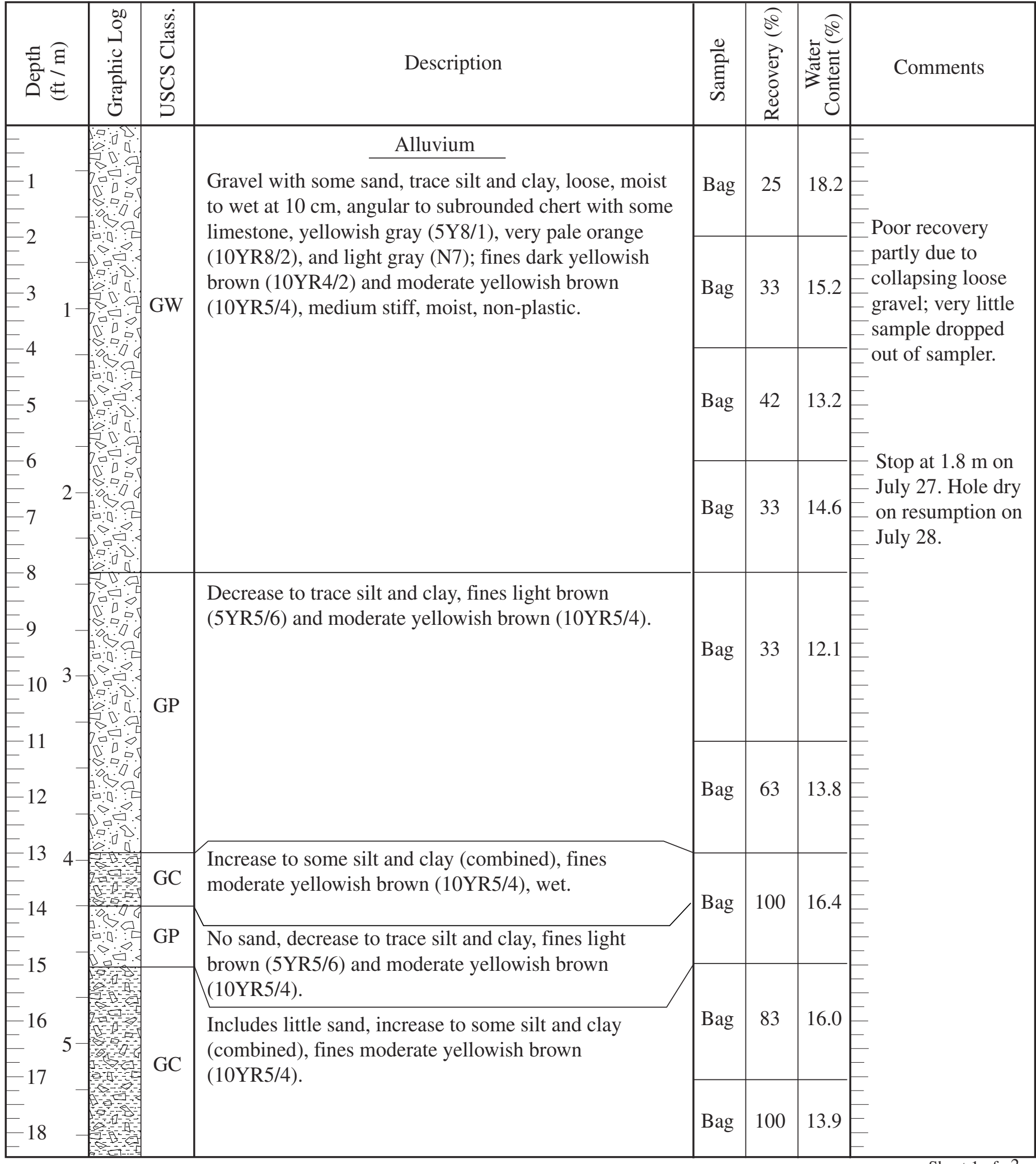


Project_Logan Cave

Date_July 27-28, 2004

Borehole/Probehole Name_GS-1

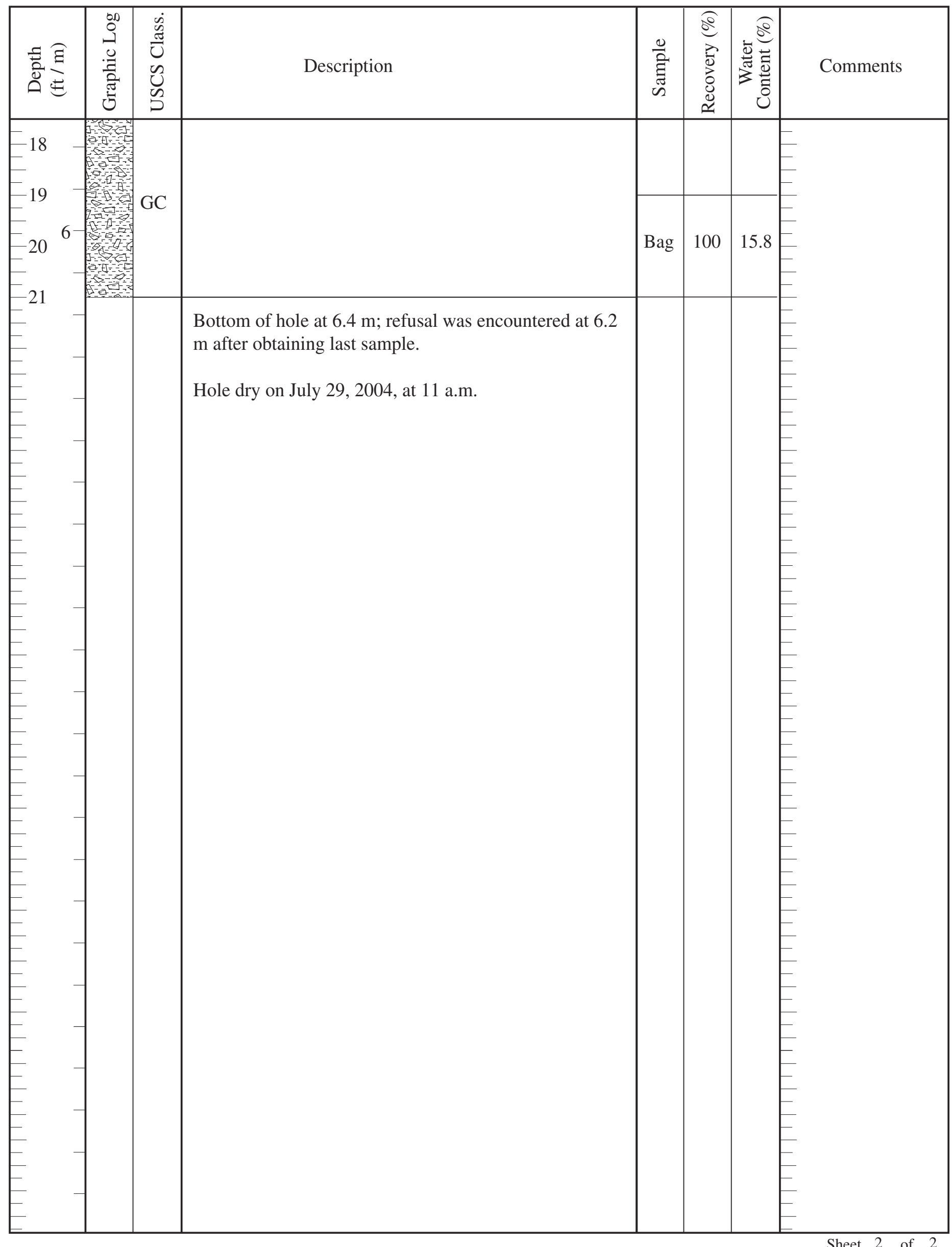




\section{U.S. GEOLOGICAL SURVEY LANDSLIDE HAZARDS PROJECT LOG OF SUBSURFACE EXPLORATION}

Project_Logan Cave

Borehole/Probehole Name

GS-2

Location_Outside of the southeast side of the cave entrance

Date

July 27,2004

Exploration Equipment_Geoprobe macro-core (0.6-m long), electric hammer Geologist_Bill Schulz/Jon McKenna

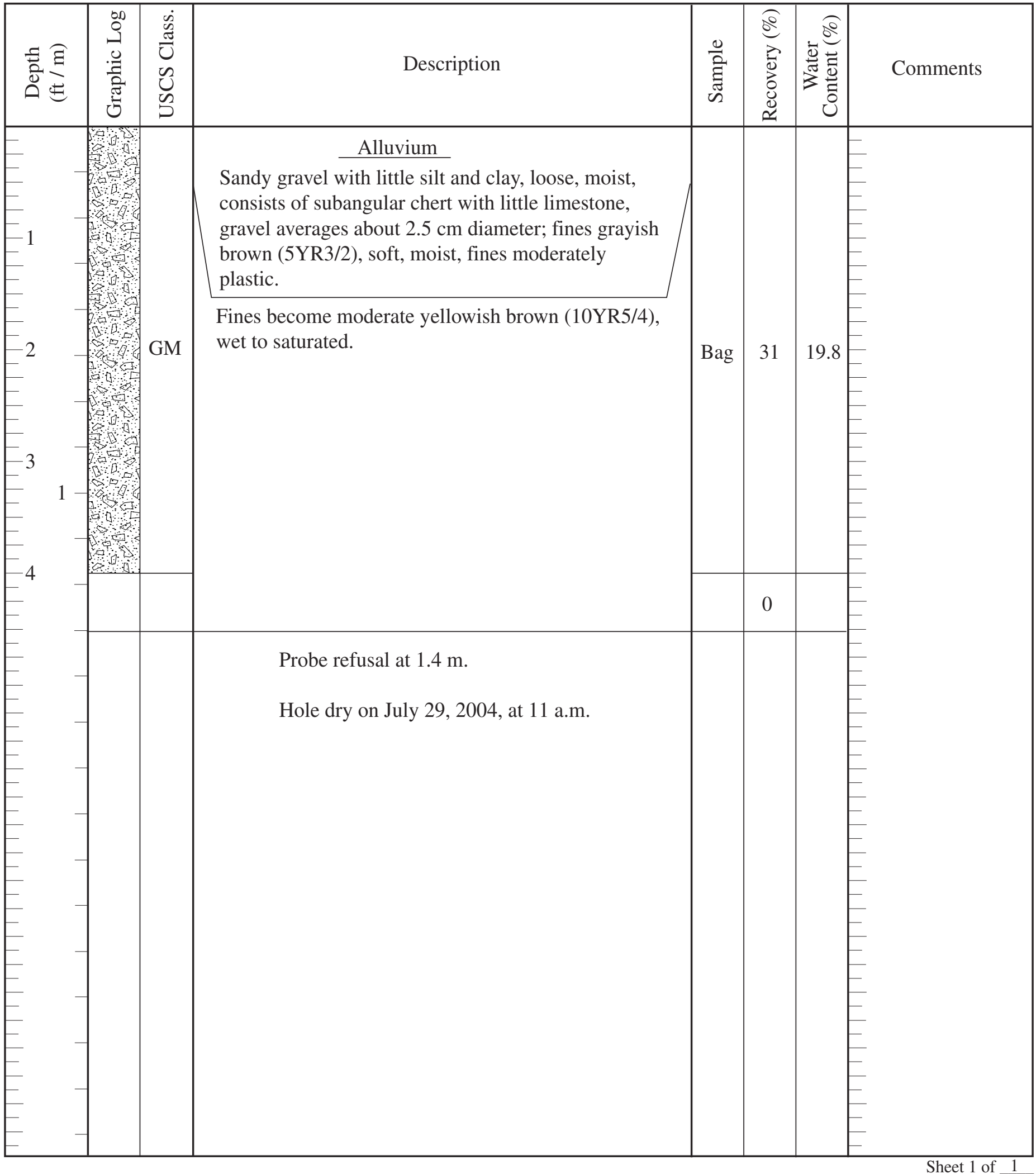




\section{U.S. GEOLOGICAL SURVEY LANDSLIDE HAZARDS PROJECT LOG OF SUBSURFACE EXPLORATION}

Project_Logan Cave

Borehole/Probehole Name

GS-3

Location_Outside of the central part of the cave entrance (2 m north of GS-2)

Date

July 28, 2004

Exploration Equipment_Geoprobe macro-core (0.6-m long), electric hammer Geologist_Bill Schulz/Jon McKenna

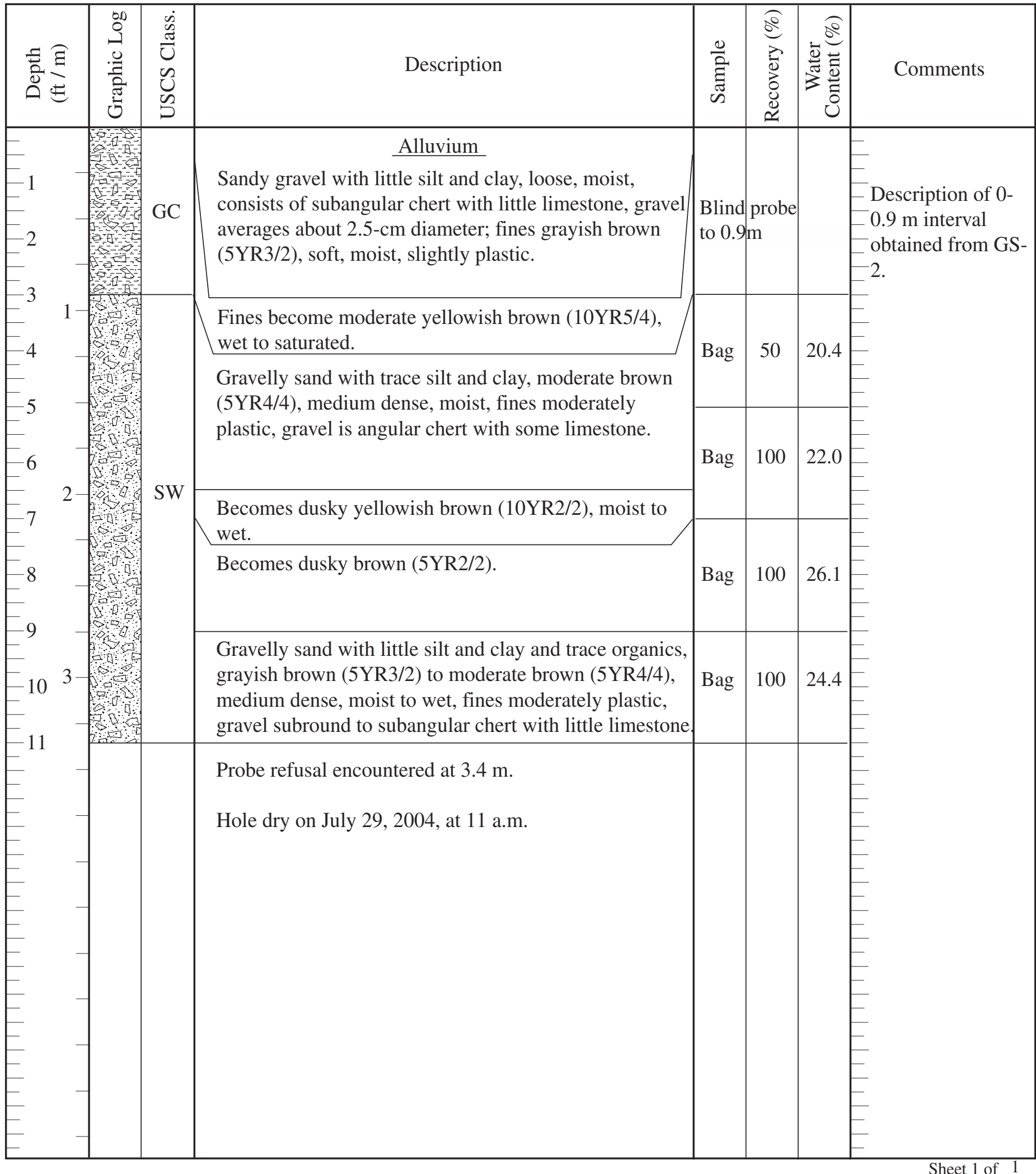




\section{U.S. GEOLOGICAL SURVEY LANDSLIDE HAZARDS PROJECT LOG OF SUBSURFACE EXPLORATION}

Project__Logan Cave

Borehole/Probehole Name

GS-4

Location_Upslope and east of sinkhole

Date

July 28, 2004

Exploration Equipment_Geoprobe macro-core (0.6-m long), electric hammer

Geologist_Bill Schulz/Jon McKenna

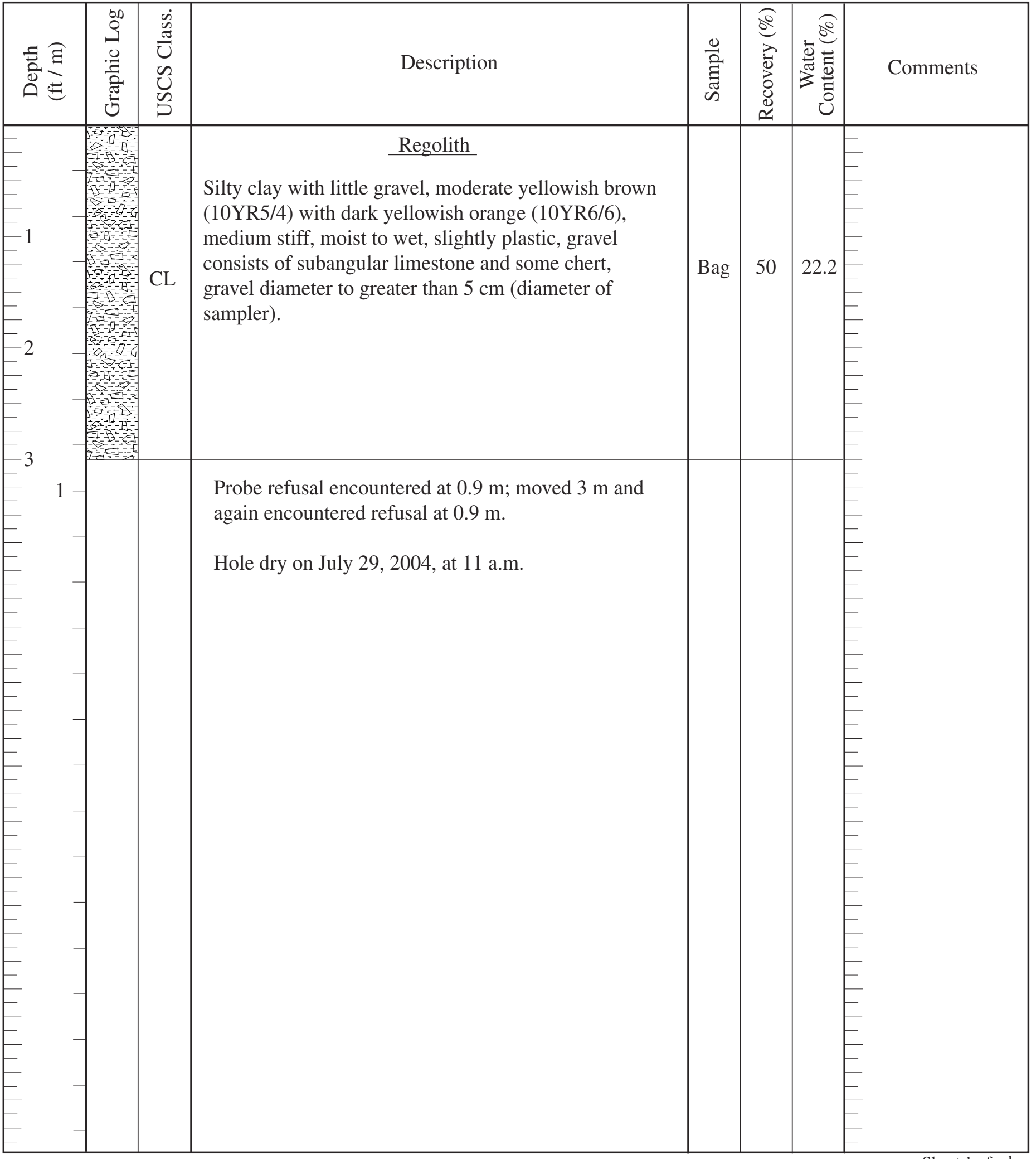




\section{U.S. GEOLOGICAL SURVEY LANDSLIDE HAZARDS PROJECT LOG OF SUBSURFACE EXPLORATION}

Project__Logan Cave

Borehole/Probehole Name

GS-5

Location_Upslope of and southeast of sinkhole

Date

July 28, 2004

Exploration Equipment_Geoprobe macro-core (0.6-m long), electric hammer Geologist_Bill Schulz/Jon McKenna

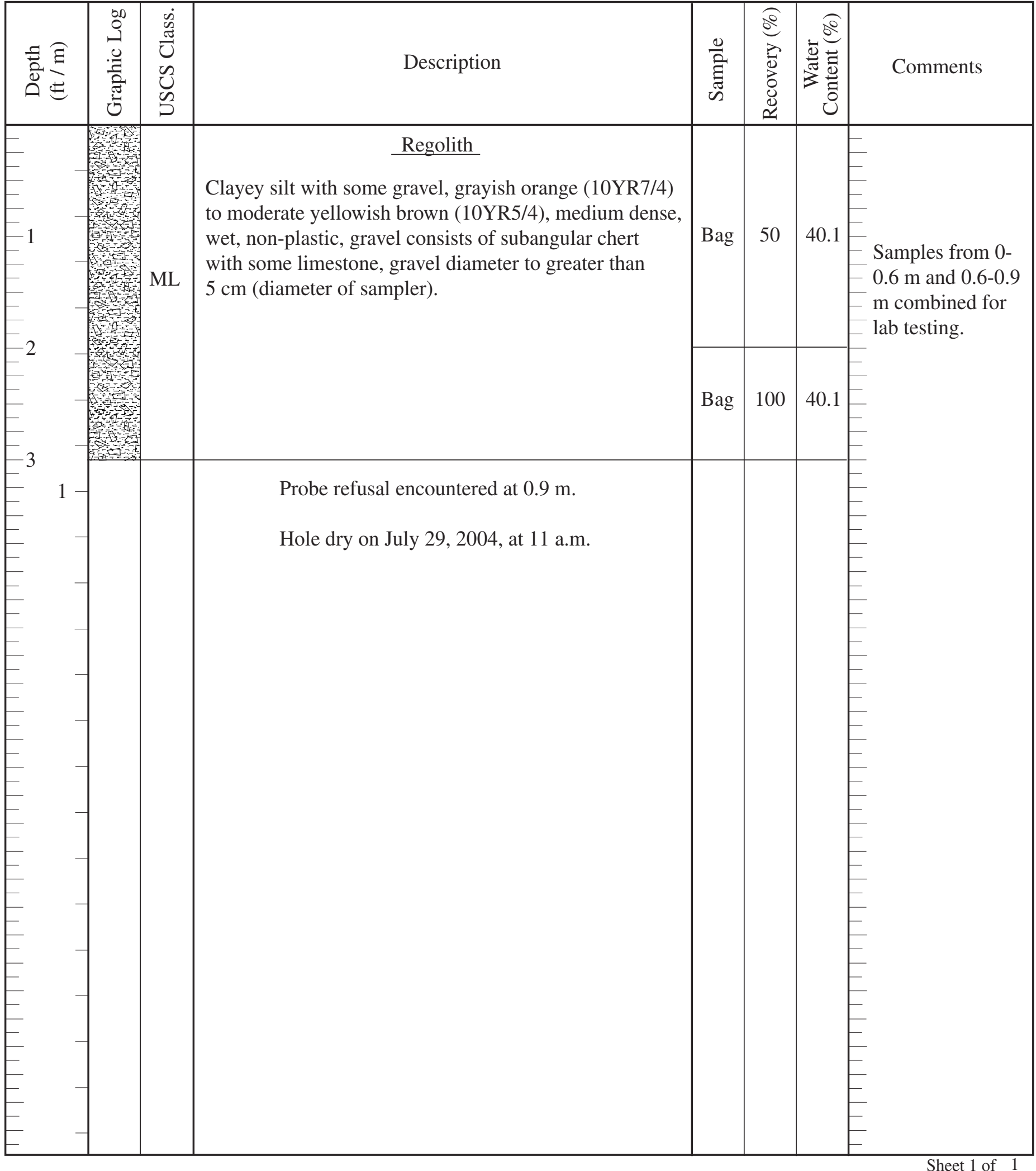




\section{U.S. GEOLOGICAL SURVEY LANDSLIDE HAZARDS PROJECT LOG OF SUBSURFACE EXPLORATION}

Project__Logan Cave

Borehole/Probehole Name

GS-6

Location_Upslope and south of sinkhole, $4 \mathrm{~m}$ west of GS-5

Date

July 28, 2004

Exploration Equipment_Geoprobe macro-core (0.6-m long), electric hammer Geologist_Bill Schulz/Jon McKenna

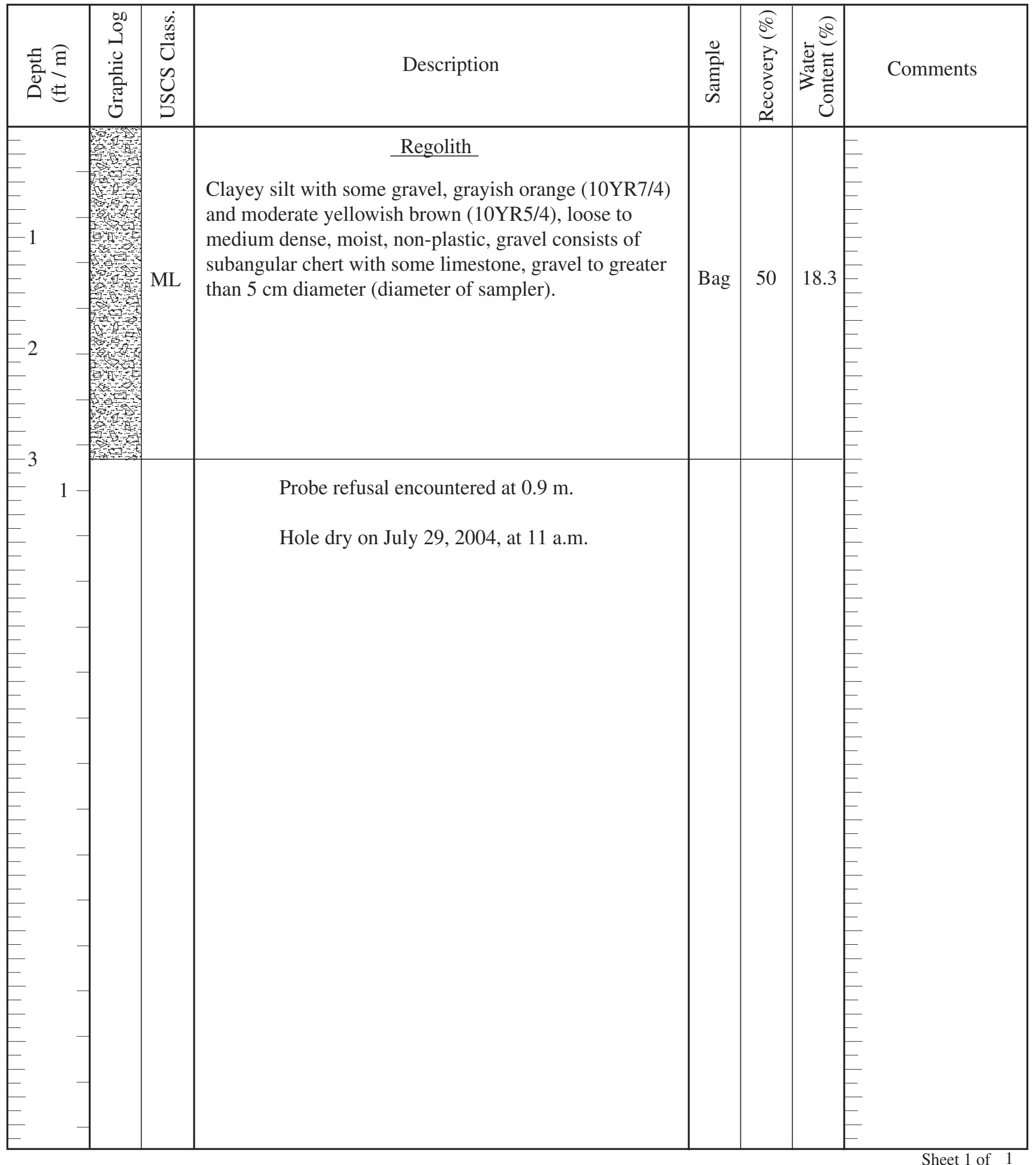




\section{U.S. GEOLOGICAL SURVEY LANDSLIDE HAZARDS PROJECT LOG OF SUBSURFACE EXPLORATION}

Project__Logan Cave

Borehole/Probehole Name

GS-7

Location_Upslope and east of the sinkhole

Date__ July 29, 2004

Exploration Equipment_Geoprobe macro-core (0.6-m long), electric hammer Geologist_Bill Schulz/Jon McKenna

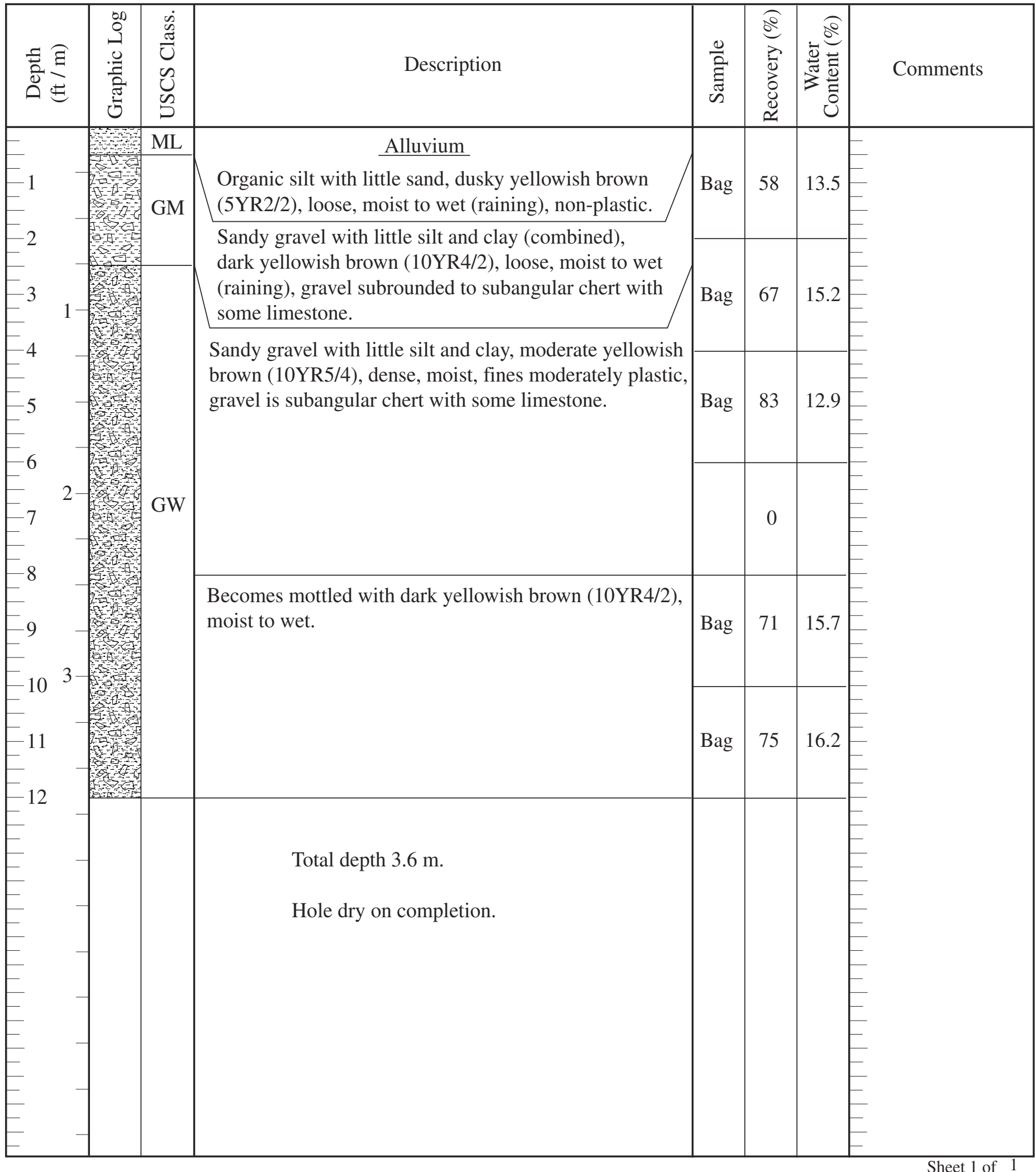


APPENDIX B

Laboratory Test Results 


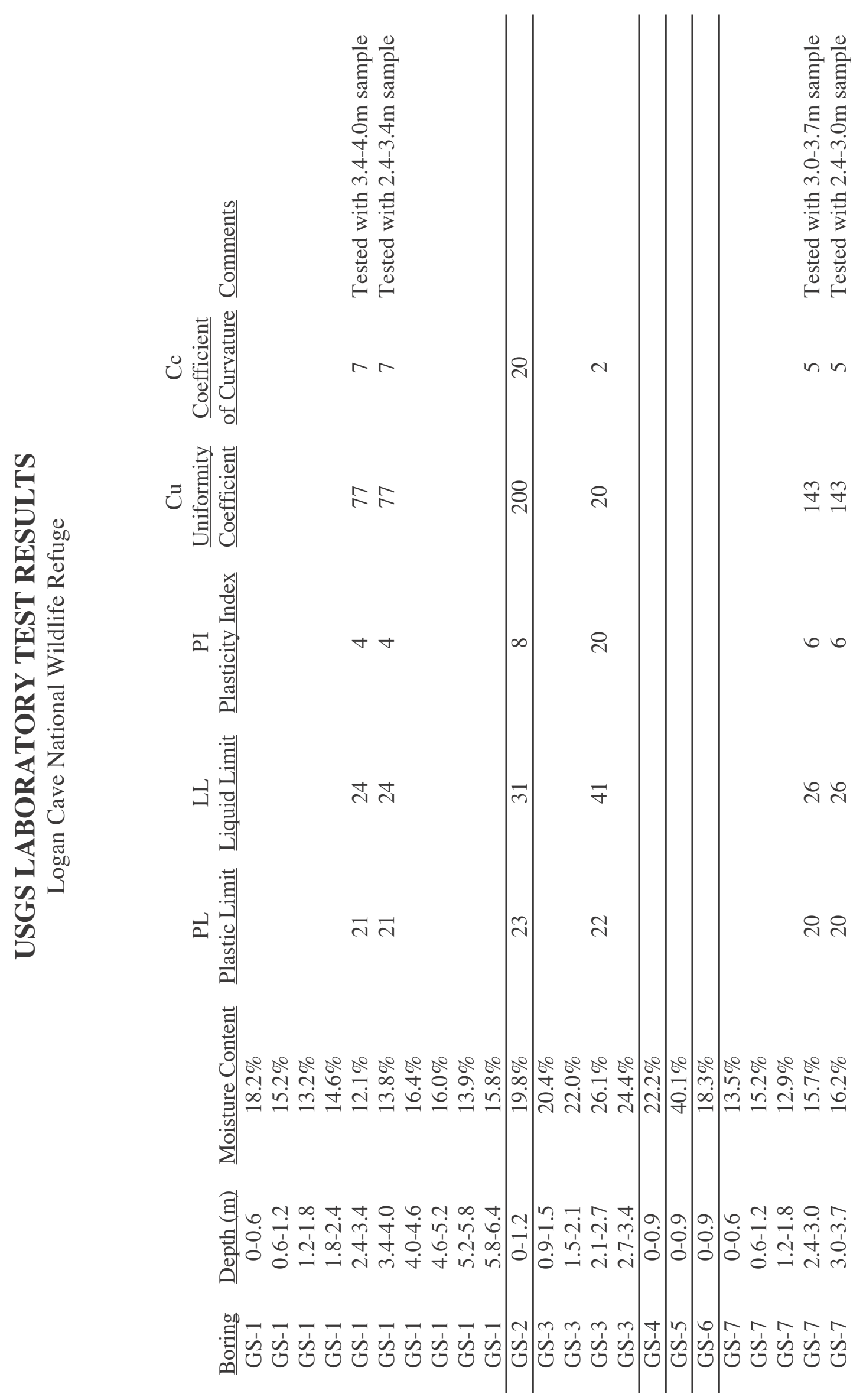




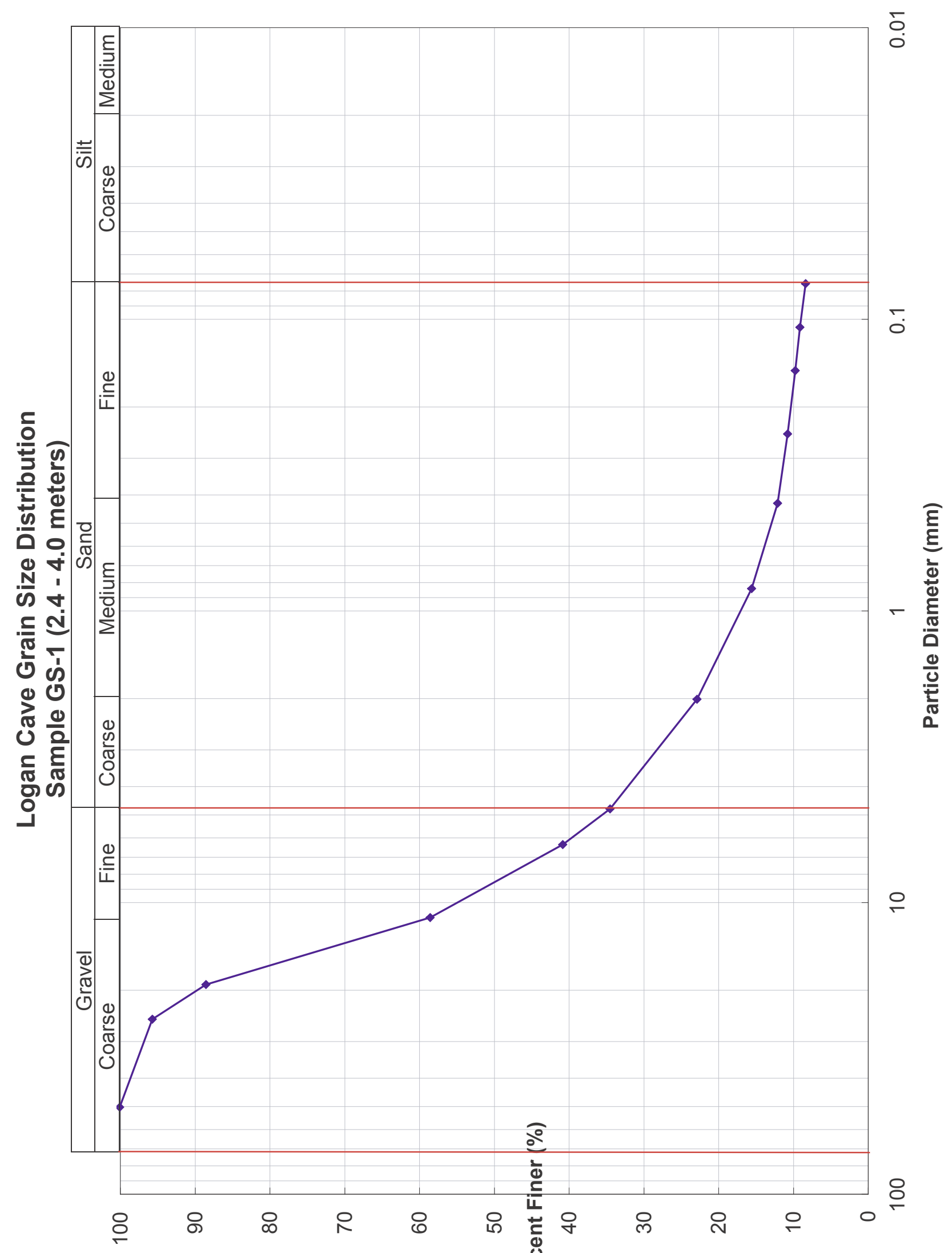

(\%) גәน!ฺ ұนәว.มd 


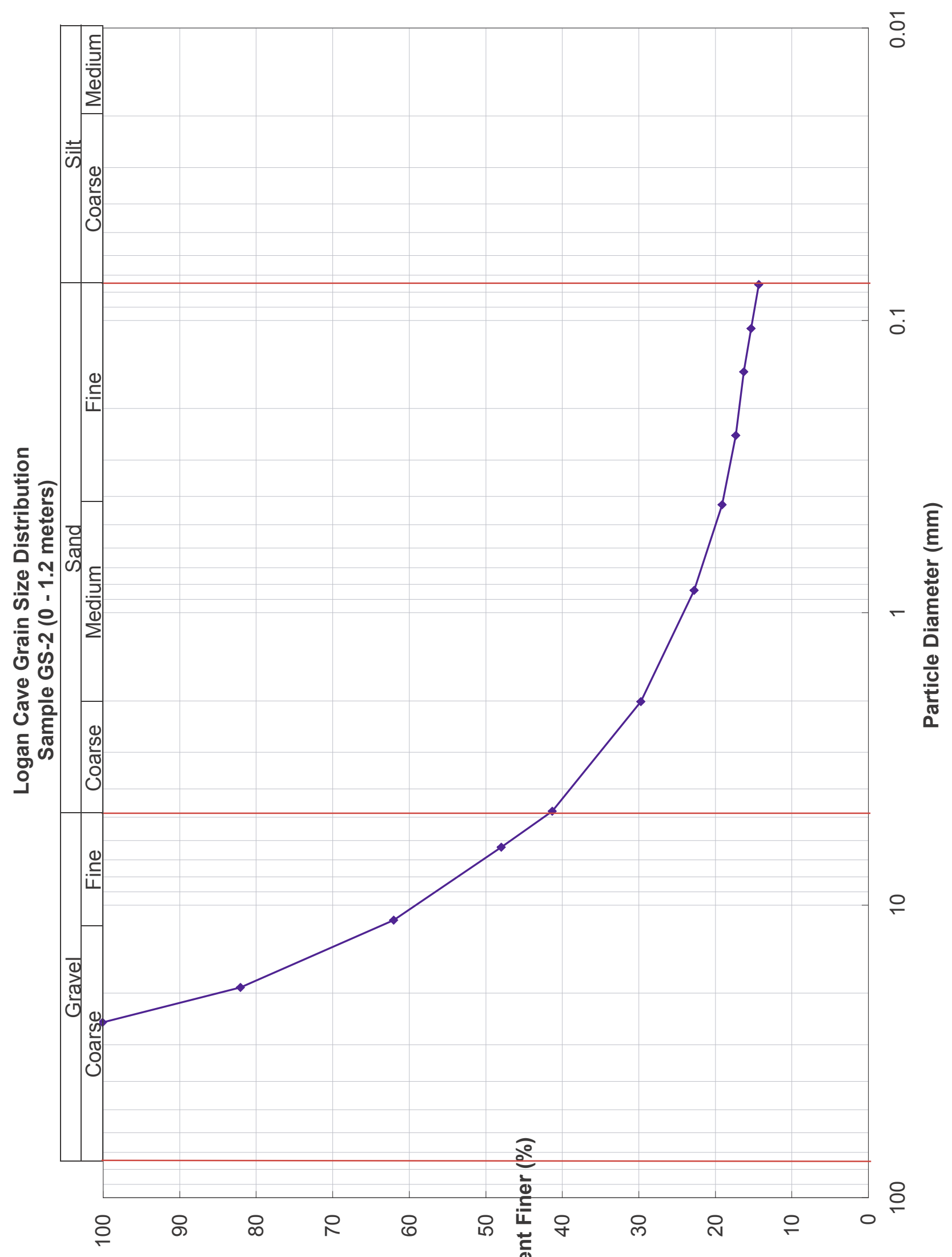

(\%) มәน!ฺ ұนәวมәd 


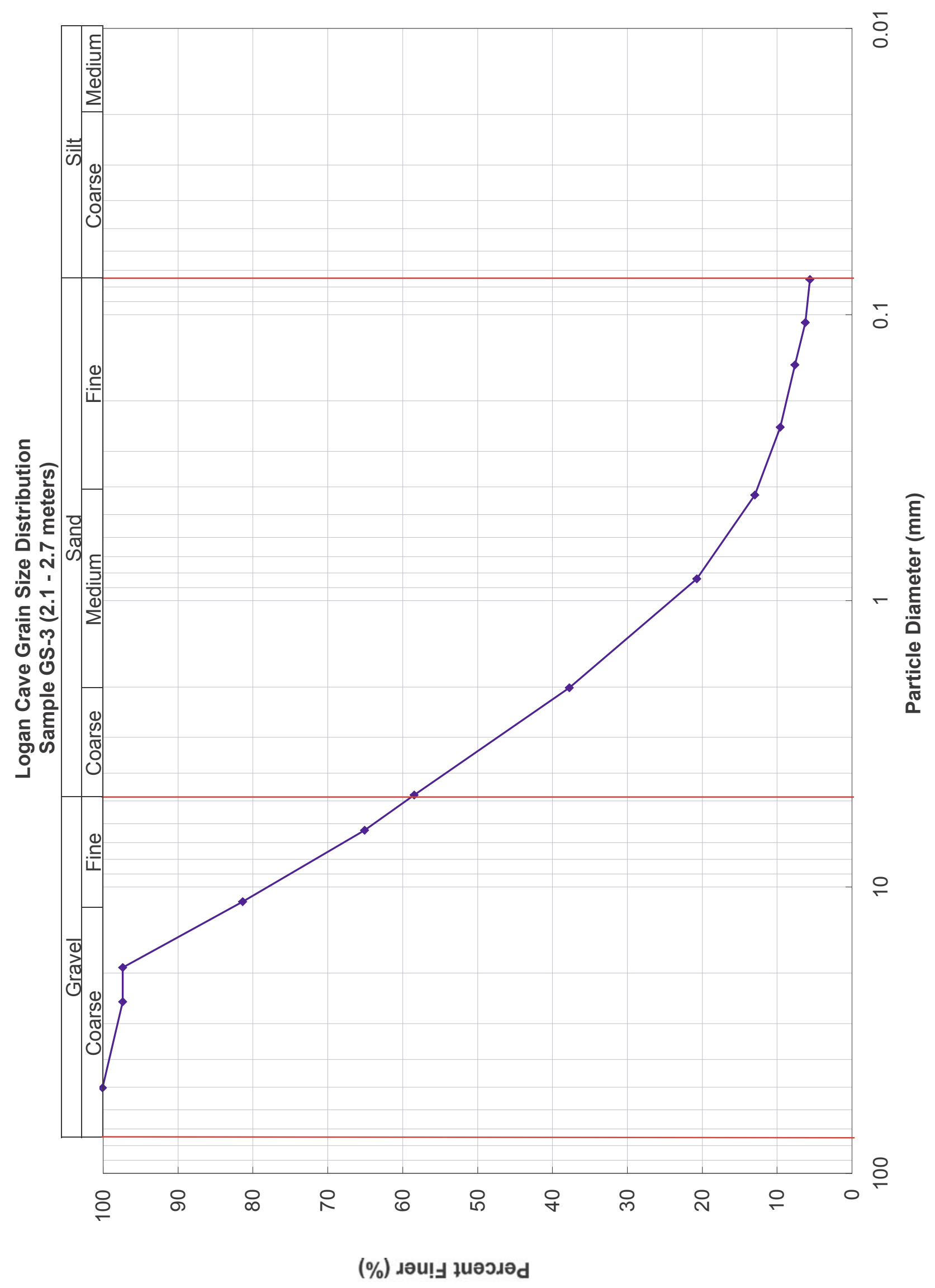




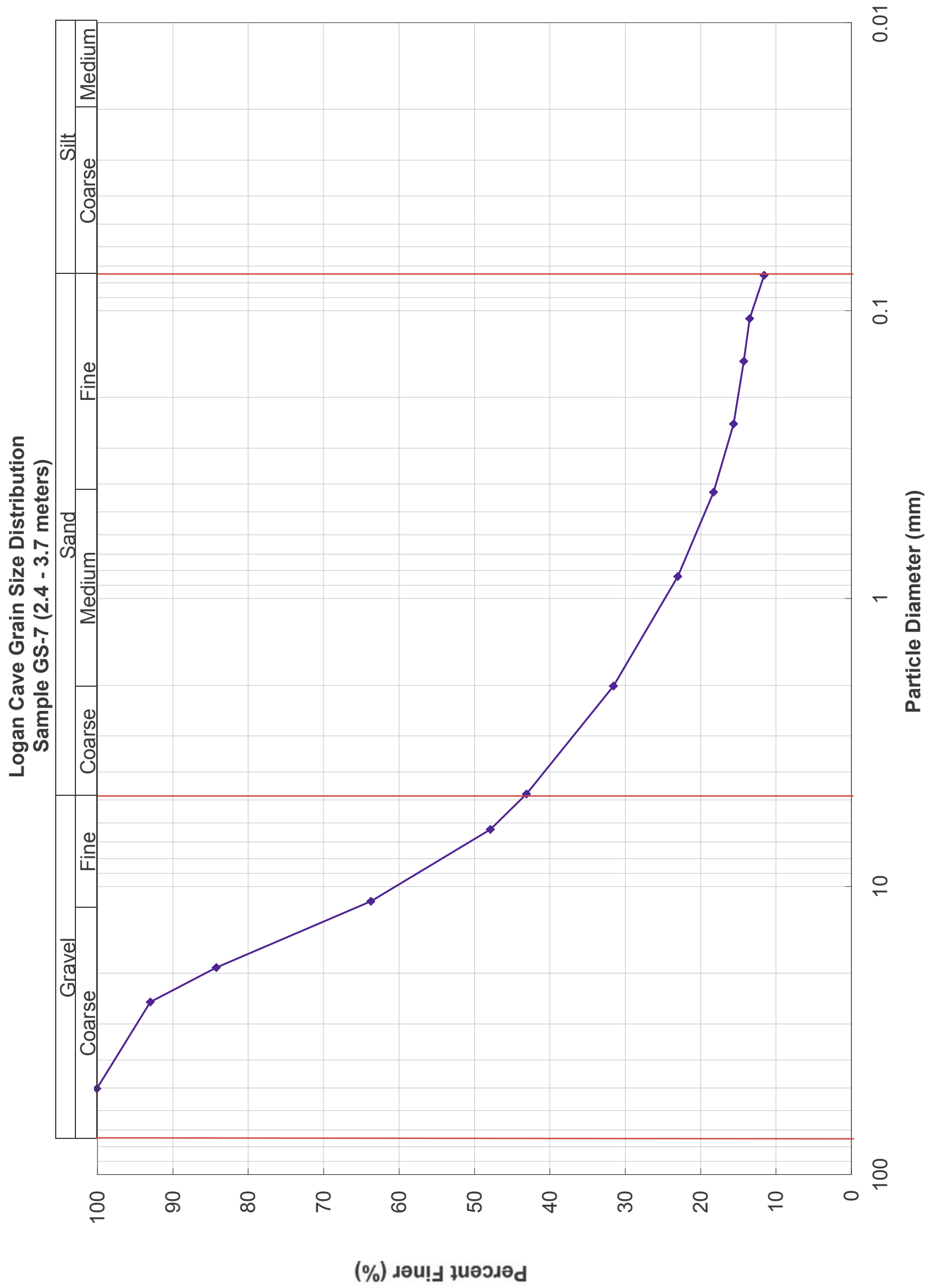




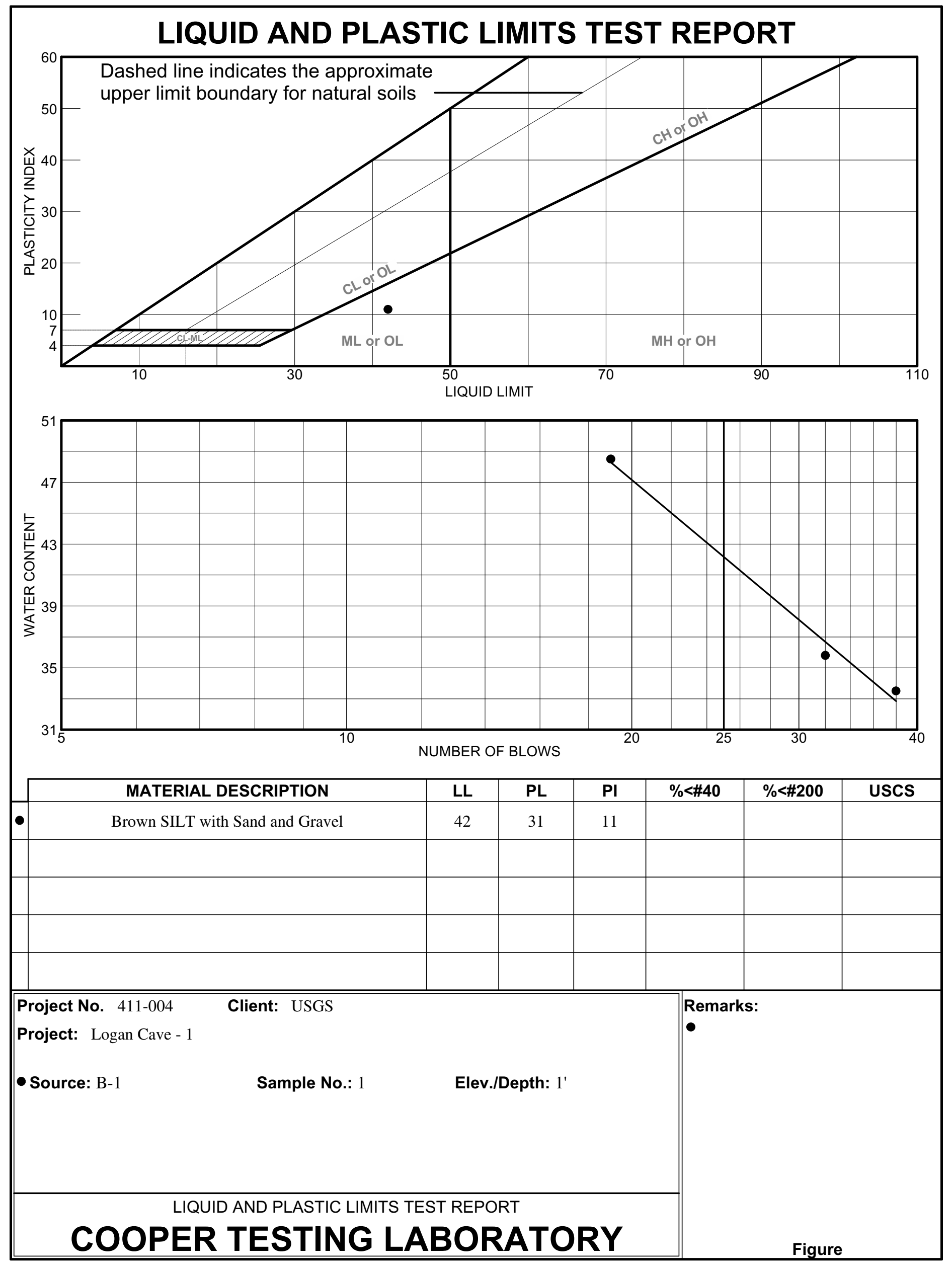




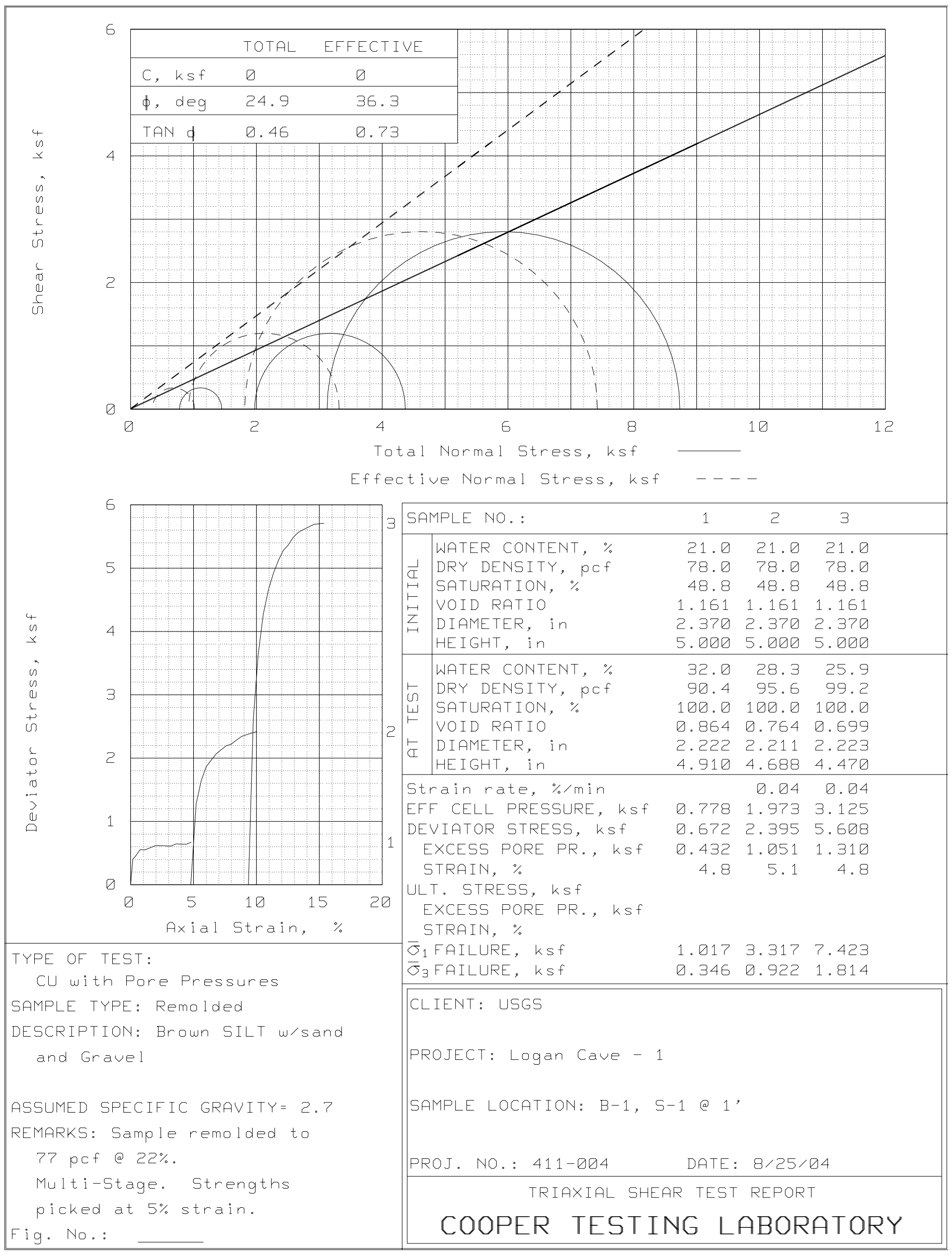




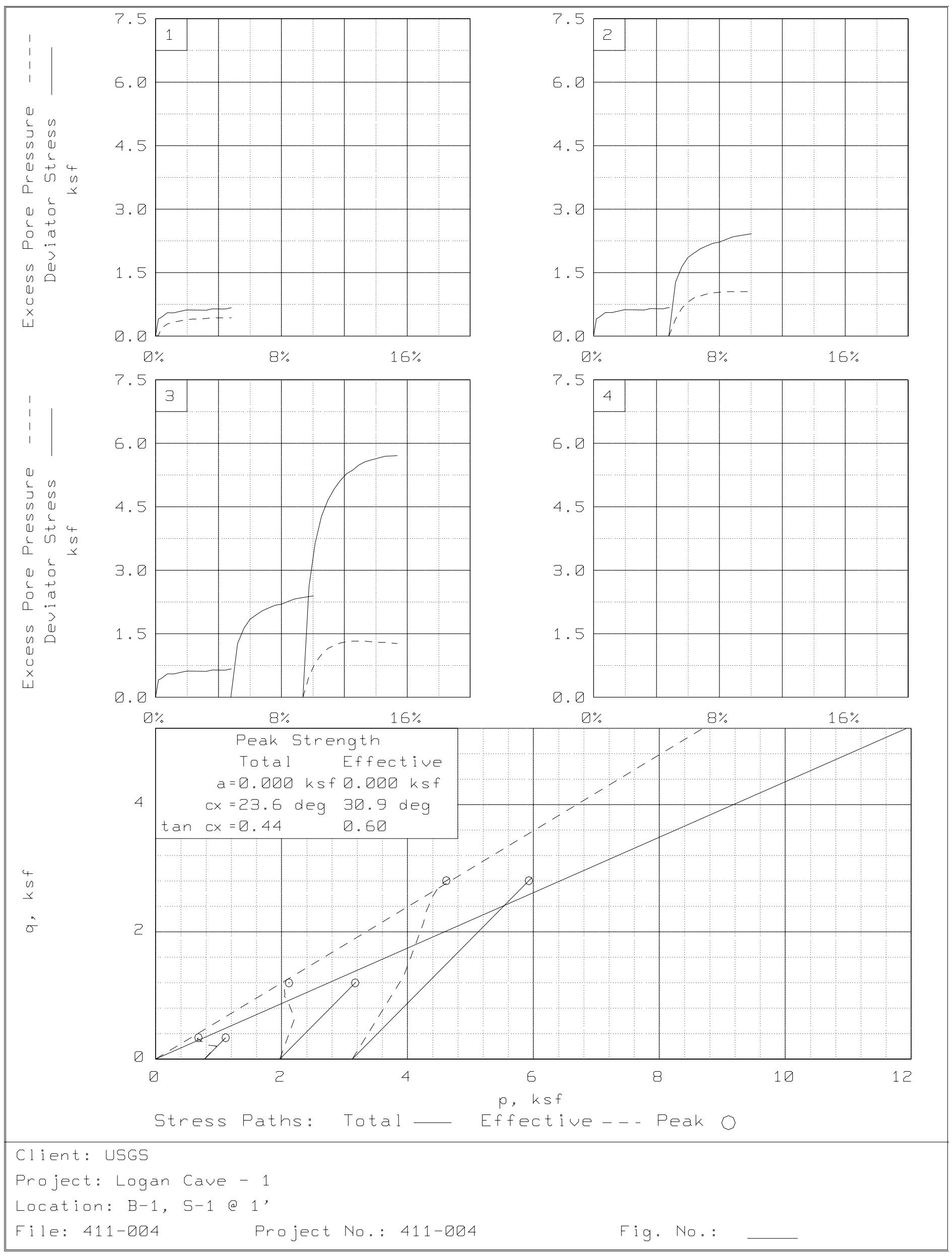

